\title{
Vancouver's Waterfront and Longshore Labour in 1918: Background Context to James Shaver Woodsworth's On the Waterfront
}

\section{Chris Madsen}

\begin{abstract}
James Shaver Woodsworth a travaillé sur le front marin de Vancouver entre sa démission du poste de ministre de l'Église méthodiste et son retour à Winnipeg et pour devenir un politicien travailliste et démocrate. La description qu'il a publiée de cette expérience est présentée et reproduite ici afin de mettre en contexte la nature de l'emploi des débardeurs, le syndicat auquel les hommes appartenaient et les luttes qu'ils ont collectivement menées. Cela va révéler ce que Woodsworth a choisi de discuter et de ne pas discuter.
\end{abstract}

James Shaver Woodsworth was a prominent social democratic politician from Western Canada. Elected six consecutive times to the House of Commons as a member of parliament representing the residents of Winnipeg North Centre and as leader of the Labour Party and the Co-operative Commonwealth Federation (CCF) Party, he championed the interests of ordinary working people toward creating a better society in Canada. A popular heritage minute video produced by Historica Canada used in grade school curriculum focuses on his unwavering stance on getting legislation for old age pensions from a Liberal minority government. ${ }^{1}$ This accomplishment was but one of many during his long career. He died on 21 March 1942 in Vancouver at the age of sixty-seven while still holding political office. Woodsworth genuinely believed in improving the economic and social lot of those who toiled for a living, as expressed in his public oratory, politics, and published writings.

On the Waterfront, published by Mutual Press in Ottawa sometime around 1925, is among his better known pamphlets, and widely referenced by labour, maritime, and regional British Columbia historians. The work is part personal

\footnotetext{
1 On-line at https://www.historicacanada.ca/content/heritage-minutes/js-woodsworth [accessed 5 November 2015].
}

The Northern Mariner/Le marin du nord, XXVI, No. 1 (January 2016), 31-47 
memoir, part political manifesto, and part social commentary. Woodsworth had followed his father into the Methodist church for training as an ordained minister after his post-secondary education in theology at Winnipeg's Wesley College and Victoria College at the University of Toronto. He also spent a free year around Oxford University in England and travelling in Europe. ${ }^{2}$ Although increasingly disillusioned by organized religion and its acceptance of the status quo, Woodsworth threw himself into mission work among the inner city immigrants and working poor of Winnipeg in the years before the First World War. He was appointed director of the Joint Bureau of Social Research covering Manitoba, Saskatchewan, and Alberta in 1916, but lost that job the following year for speaking out against Prime Minister Robert Borden's introduction of conscription and his public expression of general pacifist leanings that challenged wartime patriotism and support for the war. The Methodist church transferred Woodsworth to minister to a congregation on British Columbia's Sunshine Coast, isolated and distant from Winnipeg and Eastern Canada. His devoted wife Lucy and six children came with him to Gibson's Landing. ${ }^{3}$ Disillusioned, Woodsworth tendered his resignation - his third since joining the church - on 8 June 1918. It was accepted this time leaving Woodsworth with no job prospects and little money on hand. At the age of fortyfour, he went to work on the Vancouver waterfront as a labourer. The discreet chapters or sections that comprise On the Waterfront were written from his personal experiences and thoughts at that time, almost taking the form of sermons that he would have prepared in the course of his previous calling. The preacher in the man had discovered a new cause based on social justice and political involvement.

In retrospect, it is hard to believe that Woodsworth's stint working on the Vancouver docks and its description in On the Waterfront was mere happenstance. He had never engaged in hard physical labour with his own hands before. He was older and less experienced than most of the men around him and therefore disadvantaged in competing for job assignments. Given the means and social standing of his relatives, Woodsworth could also have probably secured one-way train tickets back to Winnipeg, if he had asked. Lucy Woodsworth continued working as a schoolteacher in Gibsons Landing, so he was not the sole breadwinner.

\footnotetext{
2 Kenneth McNaught, A Prophet in Politics: A Biography of J.S. Woodsworth, second edition (Toronto, 2011).

3 Betty Keller and Rosella Leslie, Bright Seas, Pioneer Spirits: A History of the Sunshine Coast (Surrey and Victoria, 2009), 51; Grace MacInnis, J.S. Woodsworth: A Man to Remember (Toronto, 1953); Winona Grace, Woodsworth's oldest child married British Columbia CCF politician Angus MacInnis (twenty-one years her senior). She was elected to the provincial legislature for Vancouver Burrard by a narrow margin against another CCF candidate in October 1941, lost the seat to the Liberal-Conservative Coalition in October 1945, lost again as a CCF federal candidate in Vancouver South in June 1949, and then won and held the federal riding of Vancouver Kingsway in the House of Commons three times for the New Democratic Party from November 1965 to her retirement in July 1974. Elections British Columbia, An Electoral History of British Columbia 1871-1986 (Victoria, 1988), 198.
} 
The decision to stay in Vancouver for a period of time and join the ranks of longshoremen was instead a conscious act. At a personal level, Woodsworth undoubtedly experienced some sort of mid-life crisis in 1918. Loss of job, sense of self-worth, and regular income unsettles many individuals in such situations, especially in an older age cohort where the flexibility of youth fades. A responsible and educated man, with a family to feed, he chose to pursue an entirely different type of employment in a city and locale strange to him. The obvious question is why? Woodsworth's motives were not entirely altruistic. His affinities were with working people and he longed to belong in some way to them, which by upbringing and circumstance had not been possible.

The nature of employment and hiring on the waterfront allowed a good entry point for him to share in the experience of working hard for wages without regular and longer term commitment. Other skilled occupations required apprenticeships and specialized training necessary for entry into strictly-controlled crafts that could only be achieved over a lifetime. Woodsworth simply had neither the time nor inclination. In November 1918, he paid a ten dollar initiation fee and was accepted for membership in the International Longshoremen's Association Local 38-52 Auxiliary. ${ }^{4}$ He rented a room in a house at 1218 Howe Street from Ernest Winch, the union auxiliary's secretary and president of the Vancouver Trades and Labour Council. The men who worked on the waterfront, in his view, were somehow noble and suffered from the unfairness inherent in the system that Woodsworth the nascent politician came to oppose by his soul and being.

Woodsworth never intended to stay long on the waterfront and physically probably could not have even if he had wanted without wearing out his body and mind. That was the point - no worker should be put in that situation. Woodsworth was above all a voyeur, an interested observer. His actual working hours on the docks were limited and certainly left ample time for labour educational activities, real and imagined political parties, and writing. Above all, the waterfront work experience afforded Woodsworth street credibility among workers for understanding their interests and concerns before entering the larger political sphere. It was his way of becoming a real representative of the people. For Woodsworth, the docks were the figurative trenches in the struggle for a fairer and better society.

Woodsworth's time on Vancouver's waterfront, though lasting less than a year in duration, left a lasting impression on his psyche. Of course, On the Waterfront stands out as a literary vehicle to advance certain political views and observations of the world perceived by Woodsworth. It reflects his prejudices and personal

\footnotetext{
${ }^{4}$ Pacific Coast District ILA member book, MG 27 III C7 James Shaver Woodsworth reel H-2279 vol. 15 file 11, Library and Archives Canada, Ottawa (hereafter LAC); a biographer asserts that Woodsworth was fast-tracked into the union because he volunteered to care for a seriously sick business agent stricken with Spanish influenza ravaging Vancouver in October 1918 when no one else would, according to information from Ernest Winch. McNaught, 90.
} 
interpretation of the events and forces shaping Canadian society and the common people for whom he aspired to understand and advocate on behalf of. The portrayals of individual longshoremen, for instance, by emphasizing type instead of personality are highly stereotypical. Woodsworth met and interacted with a variety of people in the course of his work hours. Who were these men, where did they live, and what were their backgrounds? The names of individuals working on the waterfront is a starting point. Reference to union membership lists, federal census returns, city directories, provincial vital records, marriage licences, municipal property assessments, military service records, and where possible materials kept by family descendants provide necessary details to build a reasonably accurate data set for persons identifying as longshoremen and stevedores. ${ }^{5}$ In Vancouver, wageearning males were required to pay a toll tax. Addresses, for example, allow plotting of residences in relation to each other and the main workplaces along the harbour of Burrard Inlet. Such a data set can be useful to aggregate further age, nationality and ethnicity, marital status, and incomes among self-identifying longshoremen. The University of British Columbia's Special Collections possesses taped interviews from an oral history project undertaken by retirees in the early 1970s, but technological obsolescence and deterioration makes access without transcriptions. ${ }^{6}$ Large numbers of casual and transitory workers engaged at one time or another on Vancouver's waterfront prove a greater challenge for maritime historians. Woodsworth mentions them in passing, but they still remain largely unknown and unrecognized.

The context behind the methods of hiring and performance of tasks by men engaged in longshore work deserves some greater clarification. Though capturing the essence, Woodsworth offers little detail about organization on the waterfront and the process by which ships arrived in port to be unloaded and loaded according to set schedules.

Shipping agents and representatives either hired men themselves or contracted local stevedoring companies to do the work. The two leading companies in Vancouver at that time were Empire Stevedoring and Contracting Company with an office at 301, 325 Howe Street, and Victoria and Vancouver Stevedoring

\footnotetext{
${ }^{5}$ Stevedores were technically persons who employed or supervised gangs of longshoremen. However, older and more experienced longshoremen called themselves stevedores as a mark of status and skill. In late nineteenth century British Columbia, "stevedores" was generally more widely used to describe waterfront workers, though "longshoremen" gained greater currency during the early twentieth century, particularly in North America. In Great Britain and Europe, they were generally referred to as dock workers.

${ }^{6}$ These oral interviews form part of the International Longshoremen's and Warehousemen's Union (Canadian Area) fonds SP17:1-SP:36, extracts from which were used in writing a union history. Inventory prepared by Kathleen Carney and Trevor May, 3 December 1992. Other records kept by the union have been affected by two arson fires at the Maritime Labour Centre. The latest in January 2015, resulted in smoke and water damage and a subsequent move to new premises on Kingsway. The international union's librarian from San Francisco has been advising on conservation, retention, and disposition.
} 
Company located on the Grand Trunk Pacific dock. William Crawford, a wellknown figure in the harbour and marine community, bought out interests in Empire Stevedoring and Contracting from Walter Dockrill, the first president of the Marine Association of British Columbia. This body was in 1916 registered as a society under the name Shipping Federation of British Columbia. It represented most shippers and waterfront employers serving Vancouver. The Shipping Federation's secretary and manager until December 1923 was Captain James R. Stewart, while a rotating president was chosen annually from member shipping and stevedoring companies. ${ }^{7}$ Captain David Baird was vice president and manager of Victoria and Vancouver Stevedoring Company, which was owned by American interests in Puget Sound though operated independently. He and his company worked closely with affiliates in US ports along the Pacific Coast and shared information on cargo rates and prevailing wages for longshore work. ${ }^{8}$ Underneath managers like Crawford and Baird, the regular salaried employees of the stevedoring companies were foremen and supervisors. When ships arrived in port and work was available, they used the "shape-up" or ship-side pick to select men lined up outside the docks waiting for work. ${ }^{9}$ The shape-up was completely arbitrary and granted enormous power to foremen who chose favourites amongst the most experienced, the hardest working, and the best known. Other men waiting and longing for a job, as Woodsworth describes, were frequently left out if no more work was available. If not picked, men would run quickly to another location along the waterfront where selection was still going on. ${ }^{10}$ The availability of work depended entirely on the number of ships in port at any one time.

By 1918, much of the daily assignment of longshore work in Vancouver, called the dispatch, was left to the union halls at 802 Pender Street (ILA Local 38-52) and 152 East Cordova Street (ILA Local 38-52 Auxiliary), to whom the stevedoring companies notified numbers required, job location, and type of cargo. Dispatch occurred three times per day - morning, afternoon, and evening. Those men not chosen in the first dispatch waited for the second or third. The change, however, was really a modified variation of the shape-up, as union officials, most particularly

\footnotetext{
${ }^{7}$ Letter, F.W. Peters to Captain J.R. Stewart, 31 December 1923, AM 279 Shipping Federation of British Columbia 521-C-2 file 3, City of Vancouver Archives.

${ }^{8}$ Letter, David Baird to O.S. Swenson, 27 September 1921, ILWU-Canada file "General material thru 1965," ILWU Anne Rand Library, San Francisco.

9 James Robert Conley, "Class Conflict and Collective Action in the Working Class of Vancouver, British Columbia, 1900-1919," PhD dissertation (Ottawa: Carlton University, 1986), 473-474. The shape-up persisted on the Vancouver waterfront until 1931, when the Shipping Federation of British Columbia ceased the practice in favour of dispatching formed gangs. This policy was part of decasualization started by employer associations in Seattle and San Francisco that spread to British Columbia. Francis Patrick Foisie, "Decasualizing Longshore Labour and the Seattle Experience," North-West History Room, Tacoma Public Library; Marvel Keller, Decasualization of Longshore Work in San Francisco,(Philadelphia, April 1939), 9-10.

10 Andrew Parnaby, Citizen Docker: Making A New Deal on the Vancouver Waterfront 19191939,(Toronto, 2008).
} 
the business agent and secretary, wielded significant influence in selection. Woodsworth had an "in" with Ernest Winch, his landlord, sponsor, and secretary of the ILA Local 38-52 auxiliary. Winch, an immigrant from England resident in Canada since 1903, was five years younger than Woodsworth. In regards to opposition to the war and socialist sympathies, both men shared much in common. ${ }^{11}$ Winch had become devoted and loyal to the longshore union.

The union encouraged the practice of dispatching gangs of longshoremen. A gang could vary in number depending on the job and allotted tasks, but the standard was thirteen men: a hatch tender, a double winch driver, a winch driver, two side runners, six men in the hold three on each side, and two working the slings topside. The hatch tender, generally a rated person with the most seniority, was the leader of the gang and responsible to the foreman. Ships carried derricks and winches onboard since lifting facilities on shore were limited. Winchmen amongst the longshoremen, not the ship's crew, manned these devices under direction of the hatch tender. Standing at a vantage point with clear sight lines, the hatch tender used standard hand signals and vocal commands to orchestrate the complex operation of cargo handling.

Most cargo was hand-stowed, that is carried on the shoulder or by handcarts (referred to by Wordsworth as trucks). It was bundled in sacks, crated, or shovelled if in loose form such as coal. Longshoremen transferred cargo to the dock for placement on other ships, trucks, or straight into railcars on spur tracks. Freight handlers and warehousemen typically worked for the shipping companies and railroads directly, being paid less on an hourly basis than longshoremen. The wage rates longshoremen received were comparatively speaking good for workmen and rose significantly in the later war years due to inflation and return of international shipping to Vancouver after depressed economic conditions when demand for the province's commodities dropped and prices fell. Only wartime shipyards in the Vancouver area paid workers higher wages on the waterfront in 1918, though less than that received in Seattle. ${ }^{12}$ The numbers of longshoremen working in gangs steadily increased.

War is never good for longshore employment and the commercial shipping on which it depends. Woodsworth was fortunate to find waterfront work in 1918, when even less was available just a year or two earlier. The benefits of the Panama Canal, which substantially shortened sailing times from Vancouver to Europe and other parts of the globe, were only starting to be realized. Through the efforts of Vancouver-Centre Member of Parliament Henry Herbert Stevens, a tireless port proponent and industrial booster, the federal government financed and built a

\footnotetext{
${ }^{11}$ Dorothy Steeves, The Compassionate Rebel: Ernest Winch and the Growth of Socialism in Western Canada (Vancouver, 1977); Dale McCartney, "A Crisis of Commitment: Socialist Internationalism in British Columbia during the Great War," MA thesis (Burnaby: Simon Fraser University, 2004), 93.

${ }_{12}$ Chris Madsen, "Wages, Work and Wartime Demands in British Columbia Shipbuilding 191619,” BC Studies, 182 (Summer 2014), 102-107.
} 
waterfront grain elevator, the first one operating in British Columbia, and a large new government-run pier east of Hastings Mill, both completed in 1914. ${ }^{13}$ Plans for the harbour in Vancouver and its facilities for receiving and exporting goods anticipated further expansion and greater trade after the war. In that sense, the equation of supply and demand on the labour side counted in Woodsworth's favour. It was the best, not the worst, of times to work on the waterfront. In nearby Seattle, a fellow employed with the Federal Horticultural Board wrote his father: "If I could get in the Longshoremen's union and get \$1.05 an hour for pushing a truck with double time for overtime I might be able to do more." ${ }^{14}$ Entering a union on the Vancouver waterfront was hard and involved years of waiting, working either as a casual or a spare. It was extremely useful to know or be related to someone already in the union.

Whatever advances longshoremen enjoyed were thanks in large part to the organizing and collective bargaining done by unions representing them on the Vancouver waterfront, in British Columbia, across Canada, and down the Pacific Coast. The first longshore union in Vancouver was chartered in November 1888, and became Local Assembly 677 of the Knights of Labor, just two years after incorporation of the city and the great fire that destroyed much of the Canadian Pacific Railway town site and wharves. ${ }^{15}$ The Riggers and Stevedores Protective Association in San Francisco, dating from July 1853, was the earliest longshore union on the Pacific Coast. The Knights of Labor movement, led by Irish-American Terence Powderly, came to British Columbia from the United States, embracing all elements of labour, Catholic religious convictions, Fenian tendencies, and a disdain for strikes, though armed violence in the name of workers was an option. In December 1896, Vancouver longshoremen left the Knights of Labor, which had declined in influence, fanned sentiment and violence against the city's Asian immigrants, and faced strong competition from craft and international unions represented by the American Federation of Labor. ${ }^{16}$ Established in 1892, the International Longshoremen's Association(ILA) and its locals, steadily supplanted the Knights of Labor.

The International Longshoremen's Association spread from a base on the Great Lakes and upper New York State to Canada and the Pacific Coast. By 1900, nearly a hundred longshoremen in Vancouver belonged to ILA Local 211. Waterfront employers were not favourably disposed toward this growth of industrial unionism, which they characterized as foreign and un-Canadian. The Pacific Coast Steamship

\footnotetext{
13 Norman R. Hacking, History of the Port of Vancouver, (Vancouver, 1976); W.B.M. Hick, Canada's Pacific Gateways: Realizing the Vision, (Prince Rupert, 2011), 63-64.

${ }^{14}$ Letter Alan to father, 3 October 1918, private collection.

15 Paul Phillips, No Power Greater: A Century of Labour in B.C., (Vancouver, 1967), 13; Lisa Anne Smith, Vancouver Is Ashes: The Great Fire of 1886, (Vancouver, 2014).

${ }^{16}$ Harold Griffin, Radical Roots: The Shaping of British Columbia (Vancouver: Commonwealth Fund, Broadway Printers, 1999), 165-166; Patricia E. Roy, "The Preservation of the Peace in Vancouver: The Aftermath of the Anti-Chinese Riot of 1887," BC Studies,31 (Autumn 1976), 57.
} 


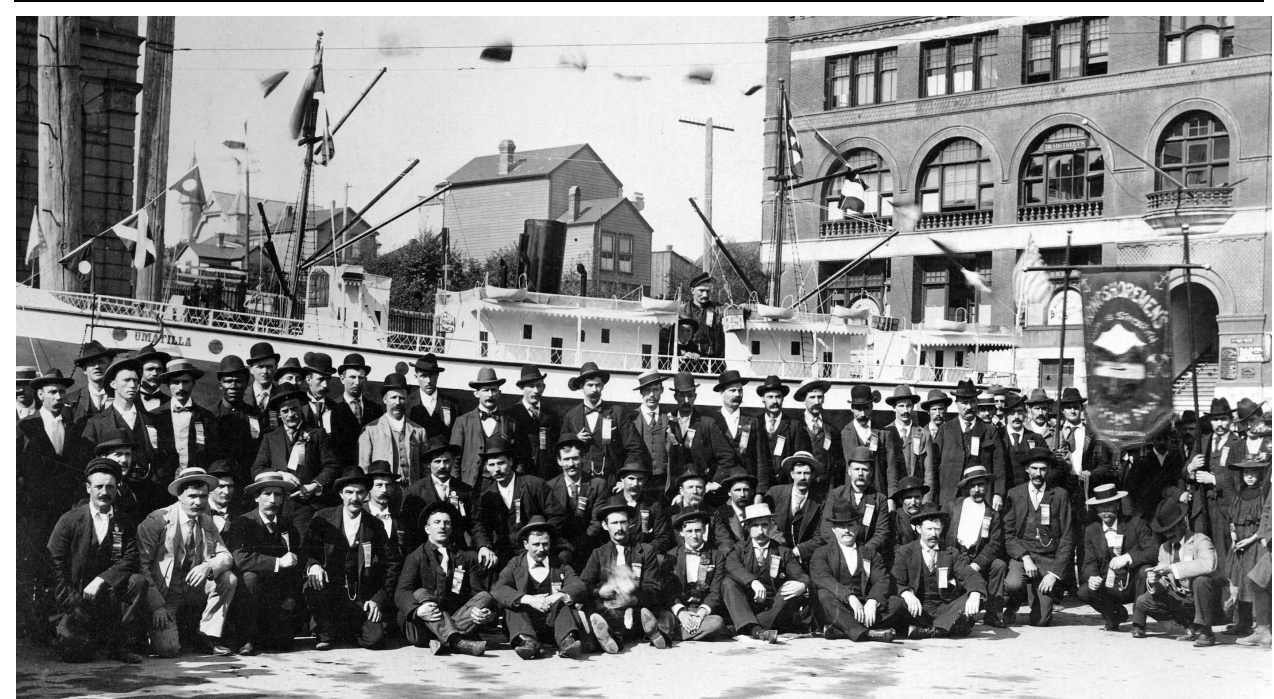

Figure 1 Longshoremen in the union belonging to the Knights of Labor parade with a ship float for Labour Day in 1895, reflecting the long tradition of unionis $m$ on the Vancouver waterfront.(Acc. No. 19777, Vancouver Public Library)

Company locked out unionized longshoremen during a five month long dispute that same year, and in 1903 ILA Local 211 organizationally fell apart after longshoremen undertook a strike against the Canadian Pacific Railway in sympathy with striking freight handlers and clerks. ${ }^{17}$ Longshoremen maintained an independent union until the International Longshoremen's Association returned to Vancouver in April 1912, for a second incarnation as ILA Local 38-52. ${ }^{18}$

At the time, the International Longshoremen's Association had twenty-four locals across Canada, of which three were in British Columbia - Prince Rupert, Victoria, and Vancouver. A negotiating team led by international president Thomas Ventry O'Connor concluded an agreement with Walter Dockrill and the Marine Association of British Columbia in May 1913 that stipulated standard pay rates based on a typical nine hour work day. Employers tried to force reductions during the wartime slump. ${ }^{19}$ In the contest for ascendency, the International Longshoremen's Association took a dominating lead by promoting higher wages

\footnotetext{
${ }^{17}$ Report of the Royal Commission on Industrial Disputes in the Province of British Columbia Issued by the Department of Labour Canada, (Ottawa, 1903), 20; J. Hugh Tuck, "The United Brotherhood of Railway Employees in Western Canada, 1898-1905," Labour/Le travail,11 (Spring 1983), 79 .

${ }^{18}$ Benjamin Hughes worked as a longshoreman for five decades, from 1888 to his retirement as a foreman 1938. He saw the transition from Knights of Labor to independent union, International Longshoremen's Association back to independent union, and then once again to International Longshoremen's Association, and he served in various executive capacities including president. 19 "Proceedings of the Sixth Annual Convention of the Pacific District of the International Longshoremen's Association held at Sailors Union Hall, San Pedro, California May 5 to 10, 1913), 101-104; "Strike of Longshoremen March 1 to April 2, 1915, Vancouver, B.C.," RG 27 reel T2691 vol. 303 file 5, LAC.
} 
and better work conditions. John Keen, the ILA Pacific District president, strongly denounced the Industrial Workers of the World, another labour movement active in the Pacific North-West and British Columbia, that tried to unite resource and maritime workers across industries and trades under, the slogan "An injury to one is an injury to all." 20 This same motto was later adopted by Harry Bridges and a new Pacific Coast union, the present International Longshore and Warehouse Union that works British Columbia ports.

ILA Local 38-52, through the efforts of business agent Gordon Kelly and president John Mahone, kept member longshoremen focussed and united during another sympathy walk-out against the Canadian Pacific Railway in July 1917. By the end of that year, the International Longshoremen's Association membership nationally was 2,884 , of which 1,300 belonged to Vancouver's ILA Local 38-52. ${ }^{21}$ In contrast, the Syndicated Longshoremen's Union in the Port of Montreal, counted among the largest unions in Canada, possessed 2,400 registered members. Montreal longshoremen, despite an earlier flirtation with the International Longshoremen's Association, stayed unaffiliated and independent during the First World War and subsequent years after. Longshore work was seasonal in Quebec due to winter conditions and freeze-up of the St. Lawrence River. In Nova Scotia, the Halifax Longshoremen's Association had belonged to the International Longshoremen's Association since July 1913. ${ }^{22}$ The principal working seaports connected by major railways in Canada were Montreal, Halifax, and Vancouver. Only the last two catered to year-round shipping, one on the Atlantic coast and the other on the Pacific coast.

Officials from the ILA Pacific District and Vancouver successfully negotiated an agreement covering wages, conditions of work, and union prerogatives with employers in effect 1 June 1918. This agreement gave deep-sea longshoremen hourly eighty cents straight time and one dollar and fifteen cents overtime for general cargo; eighty five cents and one dollar and twenty two and a half cents for lumber, and dock workers sixty five cents and one dollar. ${ }^{23}$ Hatch tenders, side runners, winchmen, and donkey machine operators received an additional ten cents per hour. Pay for loading sacks was higher if heavier than one hundred and forty pounds.

\footnotetext{
${ }^{20}$ Mark Leier, Where the Fraser River Flows: The Industrial Workers of the World in British Columbia, (Vancouver, 1990); Harvey Schwartz, Solidarity Stories: An Oral History of the ILWU, (Seattle, 2009), 144-145.

${ }^{21}$ Department of Labour Canada, Eighth Annual Report of Labour Organization in Canada (For the Calendar Year 1918), (Ottawa, 1919), 191, 210.

${ }^{22}$ Sandy MacDonald, The Halifax Longshoremen's Association 1907-2007: Celebrating 100 Years, (Halifax, 2007), 12.

23 "Wage Scales and Working Rules, Local 38-52 and Local 38-52 Auxiliary International Longshoremen's Association," 1 June 1918, MG 27 III C7 Woodsworth reel H-2279 vol. 15 file 11, LAC.
} 
Woodsworth never stayed in Vancouver long enough to learn fully the traditions and stories of struggle behind the growth of waterfront unionism. Much of that recounting of the past was passed down from one generation of longshore workers to the next working in gangs as they waited around the union hall for jobs. In retirement some even today remain very interested in their collective history. ${ }^{24}$ Woodsworth was a gentleman longshoreman, a term used by long-time longshore workers to describe someone who longshores part-time or for a short period while keeping another business venture on the side. Such persons may be full union members or just casuals. At Woodsworth's request, the International Longshoremen's Association issued a withdrawal card from the ILA Local 38-52 Auxiliary in May $1919 .{ }^{25} \mathrm{He}$ was soon back in Winnipeg in time for major labour unrest and the general strike developing there.

The leadership of longshoremen remaining in Vancouver took a radical turn. At a convention in Seattle during May 1919, Joseph Taylor from Victoria became ILA Pacific District president. ${ }^{26}$ The Canadians espoused a new way of thinking sweeping westward from Winnipeg. Workers should be organized into One Big Union, in order to have enough heft to take capital and its proponents straight on. In the ILA Pacific District, Joseph Taylor, Jack Kavanagh, and William Pritchard strongly endorsed the idea of One Big Union embracing maritime transportation workers in British Columbia, and maybe even in parts of the United States. ${ }^{27}$ Rank and file members in Seattle, fresh from a general strike in February and a waterfront strike in April, indicated strong support. Thomas O'Connor and the international executive meanwhile wanted a moderate approach, to be accepted by all locals, and any radical elements purged. O'Connor was still trying to run a continent-wide international union from Buffalo at the eastern end of Lake Erie, while spending much time in Washington, D.C. sitting on various public government committees and the United States Shipping Board. ${ }^{28}$ Brewing labour unrest in the port of New York occupied much of his time and attention. Competition between ethnic Italian and Irish longshoremen was longstanding, magnified by the growing wave of militancy and calls for greater unity with other maritime workers such as seamen. ${ }^{29}$ In this context, the Pacific Coast situation was just another maelstrom.

\footnotetext{
${ }^{24}$ ILWU Local 500 Pensioners, "Man Along the Shore”! The Story of the Vancouver Waterfront, As Told by Longshoremen Themselves, (Vancouver, 1975).

${ }^{25}$ Withdrawal card, James Woodsworth, 18 May 1919, MG 27 III C7 Woodsworth reel H-2279 vol. 15 file 11, LAC.

26 "Proceedings of the Twelfth Annual Convention of the Pacific Coast District I.L.A. of the International Longshoremen's Association held in the Labor Temple, Seattle, Washington, May 5 to $10^{\text {th }}, 1919, " 63$.

${ }_{27}$ Ronald E. Magden, A History of Seattle Waterfront Workers 1884-1934, (Seattle, 1991), 131132.

${ }^{28}$ Maud Russell, Men Along the Shore: The I.L.A. and its History, (New York, 1966), 75.

${ }_{29}$ Paul Moses, An Unlikely Union: The Love-Hate Story of New York's Irish and Italians, (New York, 2015).
} 
Thomas O'Connor, himself of Irish extraction and born in Toronto, could satisfy no one. After handing over presidency of the International Longshoremen's Association to Anthony Chlopek in 1921, O'Connor became acting chairman and then formally appointed chairman of the United States Shipping Board serving under two presidents, Calvin Coolidge and Herbert Hoover. His first order of business was to roll back longshore and maritime wages, including those on the Pacific Coast. ${ }^{30}$ Even though unsupported by O'Connor, Canadian longshoremen were active participants in the general strikes affecting Vancouver and Victoria during June 1919, partly because their local leaders advocated for the One Big Union and partly out of genuine sympathy for the plight of workers in Winnipeg and the events happening there and elsewhere. ${ }^{31}$ Woodsworth could have provided a bridge between the two locales, but his role remains imperceptible. He was certainly now far removed from affairs of the Vancouver waterfront.

As a career politician for the next two decades, Woodsworth drew upon his longshore experience when it suited. He was, however, always nostalgic for Vancouver, its moderate climate, progressive politics, and strong working people culture. Vancouver and Ottawa were his second homes after Winnipeg. Nonetheless, some notable events of 1918 important to longshoremen in Vancouver are completely missing from Woodsworth's account.

In July 1918, for three weeks Vancouver experienced a postal strike affecting most major cities and towns in Western Canada. As protest against the government bringing in strike-breakers, a meeting of the Vancouver Trades and Labour Council called upon affiliated unions to undertake a general strike, the first in the city's history. Jack Kavanagh and William Pritchard, delegates to that body, were present and spoke in favour. Memberships in ILA Local 38-52 and ILA Local 38-52 Auxiliary voted unanimously in support, Ernest Winch reported. ${ }^{32}$ For the time being, the crisis appeared averted when postal workers settled and returned to work. Then, news broke that a Dominion police constable named Daniel Campbell shot and killed Arthur "Ginger" Goodwin in the woods near Cumberland in the Comox Valley on the afternoon of 27 July $1918 .{ }^{33}$ Goodwin, a well-respected labour leader and out-spoken pacifist, had effectively organized miners and smelter workers in several communities. He was reclassified as fit for military service during a protracted strike, and went into hiding rather than go fight the Germans. Campbell claimed self-defence, though the wounds on Goodwin's body raised doubts. ${ }^{34}$

\footnotetext{
${ }^{30}$ Report on Marine and Dock Industrial Relations, prepared under direction of Commissioner T.V. O'Connor, U.S. Shipping Board covering period June 1921 to February 1922, 1 March 1922 , 87.

31 Benjamin Isitt, "Searching for Workers' Solidarity: The One Big Union and the Victoria General Strike of 1919," Labour/Le travail, 60 (Fall 2007), 32-35.

32 "Trades and Labour Council in Favour of General Strike," Vancouver Daily World, 31 July 1918.

${ }^{33}$ Susan Mayse, Ginger: The Life and Death of Albert Goodwin, (Madeira Park, BC, 1990).

34 Roger Stonebanks, Fighting for Dignity: The Ginger Goodwin Story, (Edmonton, 2004).
} 
William Pritchard went over to Vancouver Island to see firsthand and report back, while Jack Kavanagh asked openly if the killing constituted murder.

With many unions like the longshoremen already behind and willing to undertake a general strike, momentum fuelled by indignation just kept going. Carpenters in the building and construction trades, waiters, painters, and mill workers started separate strikes over wages. The Vancouver Trades and Labour Council announced that the day of Goodwin's funeral, Friday, 2 August 1918, would be a "holiday" for all workers from noon that day to noon the following day. ${ }^{35}$ The general strike was on. Vancouver's mayor, Robert H. Gale, issued a public proclamation:

To the Organized Labour of Vancouver:

On behalf of the Empire, now engaged in the deadliest of struggles, on behalf of the members of your own body who are fighting in the trenches in France and Flanders, and on behalf of the public of this city, which has given you much sympathy and endured without protest much inconvenience while you have in recent weeks been struggling for better terms, I, as chief magistrate of Vancouver, appeal to you to abandon the proposed 24-hour strike on the ground that, whatever the rights and wrongs of the matter in which it has originated, it can serve no useful purpose and do no good whatever.

I appeal to you to leave the question which has been raised as to the action of the police on Vancouver Island to a jury of your fellow-citizens there, to make your protests if, when you are fully acquainted with the facts, you believe protest is still imperative, through the regular channels and not to attempt to adjust your grievance, if grievance there be, by visiting the penalties you choose to impose on citizens, who, whatever the merits of the case, are entirely blameless.

I make this appeal in the event of the proposed action being taken. I am still reasonably confident that so far as the larger members of your body are concerned, it will prove unnecessary. ${ }^{36}$

Attempts by the mayor to reach Ernest Winch over the course of the morning proved fruitless. As instructed, 961 longshoremen collectively departed the docks when noon hour struck leaving ships half loaded in the harbour. Streetcars stopped and businesses closed for lack of workers and customers.

Large numbers of returned soldiers decided to take matters into their own hands. An ugly mob numbering three to four hundred stormed the front entrance of the Labour Temple. They came armed with a blacklist of union delegates and executives on the Vancouver Trades and Labour Council deemed to be responsible for instigating the general strike. One was thrown out a window down onto the

\footnotetext{
35 “Trades and Labor Council Endorse 24-hr Protest," BC Federationist, 2 August 1918.

36 “Mayor Makes Appeal to Have Dispute Courts," Vancouver Daily Province, 2 August 1918.
} 
pavement along with numerous papers, books, and office furniture. Jack Kavanagh hid in the building during the rampage. The soldiers roughly grabbed George Thomas, ILA Local 38-52's secretary, and forcibly made him kiss a large Union Jack flag being used as a banner by the crowd. ${ }^{37}$ Thomas managed to break free and ran down an alley into the arms of some police. He was taken into custody to a nearby station in a police car for his own protection. This level of mob violence had been unseen in Vancouver since the 1907 anti-Asian riots. ${ }^{38}$ Despite the assaults and property damage at the Labour Temple, no arrests were made that afternoon.

Mayor Gale told a mass meeting of an estimated thousand citizens and returned soldiers held at the Empress Theatre in the evening that the unruly crowds were just too large for the police to handle and that workers should return to work immediately. Private Augustus Devereaux, one of the subsequent speakers on the platform, described a great sense of betrayal going so far to say "even as the Hun leaders drive the German hordes onto British bayonets, so the labourites are being driven onto the bayonets of pointed public opinion." ${ }^{39}$ Devereaux, previously a teacher, was thirty-eight years old and born in England. Due to war wounds to half his body, he was deemed unfit for further military service and three-fifths disabled for normal civilian employment. ${ }^{40}$ For him, the refusal to work or serve, when he could no longer, was deeply personal. Devereaux expressed little sympathy for the death of Goodwin, a despicable draft evader in his eyes. Returned soldiers accused longshoremen of being unpatriotic and pro-German, a sentiment encouraged by members of the business community, a few Members of Parliament attending the mass meeting, and jingoistic headlines in at least two of the city's daily newspapers.

The next morning, at 1130 on Saturday, 3 August, another group of one hundred soldiers, including many convalescents, surrounded the International Longshoremen's Association hall at 804 West Pender Street. A phone call had been made to Shaughnessy Hospital allegedly by a person identifying as a longshoreman talking about payback for the previous day's assault on the Labour Temple and the union's secretary. Private Augustus Devereaux's active presence in the crowd, however, suggests that the action was pre-meditated rather than spontaneous.

Longshoremen retreated into the hall, closed the doors, and crowded the windows looking out wondering what might come next. If William Bennett's polemical description is to be believed, the "second attack which lasted all afternoon, held up all traffic on Pender Street West, with the whole Vancouver police force engaged, the I.L.A. men beating off every attempt to storm their hall." ${ }^{41}$

\footnotetext{
${ }^{37}$ Elizabeth Anne Lees, "Problems of Pacification: Veterans' Groups in Vancouver, 1919-1922," MA thesis (Burnaby: Simon Fraser University, 1985), 11.

38 Julie F. Gilmour, Trouble on Main Street: Mackenzie King, Reason, Race, and the 1907 Vancouver Riots, (Toronto, 2014).

39 "Angry Veterans Break Goodwin Sympathy Strike", Vancouver Daily Province, 3 August 1918.

40 "Proceedings of Medical Board at Discharge Depot - Regimental Number 154855 Devereaux, Augustus John," RG 150 acc. 1992-93/166 Box 2484-31 file 354465, LAC.

41 William Bennett, Builders of British Columbia, (Vancouver, 1937), 80.
} 
In truth, the longshoremen outnumbered soldiers nearly six to one. A bunch of cripples in an unequal fight against strong, burly longshoremen was a losing proposition. Understanding the timing remains important. In point of fact, the returned soldiers intended to shame dispatched longshoremen as they left the hall for the docks once the general strike expired at noon. In modern military parlance, it was an information operation. The demonstration was never meant to be an assault like what transpired at the Labour Temple the previous day. Ernest Winch, quite astutely, kept the longshoremen in the hall and avoided any chance of fistfights and physical violence. The union had not taken the bait, as some persons in the community behind the soldier protests might have wanted.

Most of the sparring between the two sides involved lots of shouting, a few strident demands, and impromptu speeches. The shaming began. Private Devereaux mounted the stairs and declared in choice words: "the members of the International Longshoremen's Association have shown themselves to be a lot of white-livered, miserable poltroons. They can't see the issue at stake because of the big dollar so close to their noses. You should work or be sent out where brave fellows are fighting so that you can fill your bellies in comfort and peace." 42 Several attempts by individual longshoremen to answer were drowned out by the loud crowd. The returned soldiers demanded the immediate removal of Jack Kavanagh, ILA Local 38-52's outspoken representative seen as the radical Socialist that he was; indeed, they wanted him run out of the city and the province. ${ }^{43}$ The militancy of the waterfront union, however, was very subdued, notwithstanding the personal views and leanings of some of its more prominent members on the local British Columbia scene. The International Longshoremen's Association proved unequal in the years leading up to the 1923 strike against the Shipping Federation of British Columbia, when it was supplanted by another union, the Vancouver and District Waterfront Workers Association. ${ }^{44}$ For now, talking took the place of fighting and striking. For better or worse, longshoremen were pitted against returned soldiers.

Ernest Winch and the longshore executive invited a committee of returned soldiers, including vocal spokesman Private Augustus Devereaux, inside for a parley. Mayor Robert Gale coincidently arrived on the scene shortly thereafter. Apparently, he had been driving by in his car and noticed the disturbance, or at least that was what the press was told. The hands-on approach by the city's highest elected official was unconventional. A squad of police came with him, though many members of the recently unionized Vancouver Police Force were sympathetic toward labour's demands during the general strikes of 1918 and $1919 .{ }^{45}$ A police

\footnotetext{
42 “Ask Expulsion of Ringleaders”, Daily Colonist, 4 August 1918.

43 David Akers, "Rebel or Revolutionary? Jack Kavanagh and the Early Years of the Communist Movement in Vancouver, 1920-1925," Labour/Le travail, 30 (Fall 1992), 18.

${ }^{44}$ Roy Smith, "Vancouver Longshoremen, Resilient Solidarity, and the 1935 Interruption:

Company Unionism 1923-1945,” MA thesis (Burnaby: Simon Fraser University, 2013), 14.

${ }^{45}$ Lani Russwurm, "Constituting Authority: Policing Workers and the Consolidation of Police

Power in Vancouver, 1918-1939," MA thesis (Burnaby: Simon Fraser University, 2007), 20-21.
} 
sergeant and three constables took charge of the front door keeping the returned soldiers outside and the longshoremen inside. The mayor sat down with both sides and a couple newspapermen upstairs. The Vancouver Daily World gives a very detailed blow by blow account of what was said over the course of discussion. ${ }^{46} \mathrm{~A}$ couple returned soldiers tried to climb a fire escape behind the building, but Gale and Devereaux implored the men outside from a window to allow talks to proceed unmolested. Hungry and anxious longshoremen waited inside the crowded hall.

Given his demeanour and presence at the mass meeting the night before, the frustrated mayor's sympathies were unmistakeably with the returned soldiers. After a few more hours of talking, the longshoremen agreed to work if the crowd of soldiers went away, and if another committee was appointed to meet further with representatives from the returned soldiers and hear their demands. When several longshoremen questioned Gale's professed neutrality, the mayor picked up his hat and left the room saying: "Then this is no place for me." Winch and Gale addressed the crowd outside which then dispersed and marched off under police escort to the Cambie Street military grounds, where the mayor joined them for another speech.

After consulting with higher military authorities, Mayor Gale warned that martial law was a possibility if further street disturbances and strikes continued in Vancouver. The implied threat was drastic and inherently anti-democratic, and ultimately not acted upon. In the months following, only minor altercations occurred between longshoremen and returned soldiers. As a sop to the protests, the Vancouver Trades and Labour Council elected a new slate of officers, different from those that had started the general strike. That was how Ernest Winch entered his presidency of that body. ${ }^{47}$ Gordon Kelly, now the ILA Pacific District vicepresident in Seattle, praised Winch for his handling of the whole situation and conciliatory approach. During a visit back to his hometown, Kelly met with Mayor Gale and made amends.

Gordon Kelly's stance was pragmatic though principled. His highest priority was negotiating a new 1919 collective agreement with the waterfront employer associations covering longshoremen throughout the Pacific North-West, applicable to British Columbia, Washington State, and Oregon, and the confrontations with returned soldiers represented a distraction to that goal. Unfortunately, Kelly never lived to see the fruits of his labour. He, like so many others, contracted influenza and died from complications related to lack of rest and pneumonia on 9 November 1918. ${ }^{48}$ Kelly was thirty-nine years old, the same age as Ernest Winch, and unmarried. Originally from Birmingham, he had two brothers, one a Catholic priest in British India and the other in the British secret service. Kelly purportedly turned

\footnotetext{
46 "Returned Soldiers and Longshoremen in Conference," Vancouver Daily World, 5 August 1918.

47 “President Winch's Inaugural Address," BC Federationist, 9 August 1918.

48 “Gordon J. Kelly Seriously Ill,” Vancouver Daily Sun, 9 November 1918; Margaret W.

Andrews, "Epidemic and Public Health: Influenza in Vancouver, 1918-1919," BC Studies, 34

(Summer 1977), 21.
} 
down a million dollar bribe from the German ambassador in the United States during 1916 to prolong a major waterfront strike aimed at paralysing shipping on the Atlantic and Pacific coasts. ${ }^{49}$ International president Thomas O'Connor received the same offer from the Germans, which he also declined. Any pro-German accusations were completely groundless. On 11 November 1918, the Vancouver waterfront emptied of longshoremen when city officials declared a public holiday for Armistice celebrations ending the First World War.

Marshal Wright, the ILA Pacific Coast District secretary-treasurer, accompanied Kelly's body back from Seattle to Vancouver on a steamship. Funeral parades on either end of the trip were well-attended by longshoremen and union officials. After morning visitations in the longshoremen's hall on 13 November 1918, Kelly was taken to Mountain View Cemetery on Fraser Street for burial, led by the Musicians Union band and followed by a long procession of motor cars. ${ }^{50}$ The pallbearers for the coffin were Ernest Winch, Marshal Wright, friend and former Vancouver Trades and Labour Council colleague James McVety, Joseph Taylor from Victoria, Jack Bjorklun from Tacoma, ILA Local 38-52 secretary Thomas Nixon, business agent Ambrose Reid, and Albert Wells, editor of the $B C$ Federationist labour newspaper. ${ }^{51}$ Winch, on behalf of the union, gave a heart-felt speech in recognition of Kelly's achievements and contributions to the International Longshoremen's Association. Gordon Kelly's funeral was a major event for the Vancouver waterfront union, and virtually every longshoreman attended, the stevedoring companies having given special permission for time off to do so.

Nothing whatsoever is said about this sequence of events in On the Waterfront. Did Woodsworth participate as a longshoreman? What was the dinner conversation around the table in the Winch household? What was discussed about the union struggles amongst longshoremen waiting in the hiring hall? Why was Woodsworth's memory so selective? For historians, the omission is really quite remarkable. He was very close and intimate with some of the main characters involved. As a labour politician with a caucus of members, Woodsworth certainly invoked Ginger's name, both as a martyr and someone who might have resonated with his own sensibilities and recent life back story. ${ }^{52}$ Ideologically, Woodsworth was at odds with Communists like William Bennett, and the celebration of strikes and class conflict in British Columbia. Despite attempts to come together, politics of the left in the province was oftentimes fractious and divisive. ${ }^{53}$ For the likes of Jack Kavanagh, Woodsworth was a social democratic pretender and not a real Socialist. Such things were inconvenient for the narrative that Woodsworth was trying to construct about

\footnotetext{
49 “Gordon Kelly Dead at Seattle,” Vancouver Daily Province, 9 November 1918.

50 “Gordon J. Kelly is Laid to Rest," BC Federationist, 15 November 1918.

51 “Labor Leader Laid to Rest," Vancouver Daily World, 13 November 1918.

52 Benjamin Isitt, "Elusive Unity: The Canadian Labour Party in British Columbia, 1924-28," BC Studies, 163 (Autumn 2009), 49.

${ }^{53}$ Gordon Hak, The Left in British Columbia: A History of Struggle, (Vancouver, 2013).
} 
working people and himself. He felt that Canadian society could be changed through politics based on ideals and principles.

That said, James Shaver Woodsworth's On the Waterfront remains a significant historical document of interest to maritime historians and researchers in related fields studying waterfront labour and longshoremen on Canada's West Coast at the end of the First World War. 


\section{On the Waterfront With the workers on the docks at Vancouver - some observations and experiences}

\section{James Shaver Woodsworth}

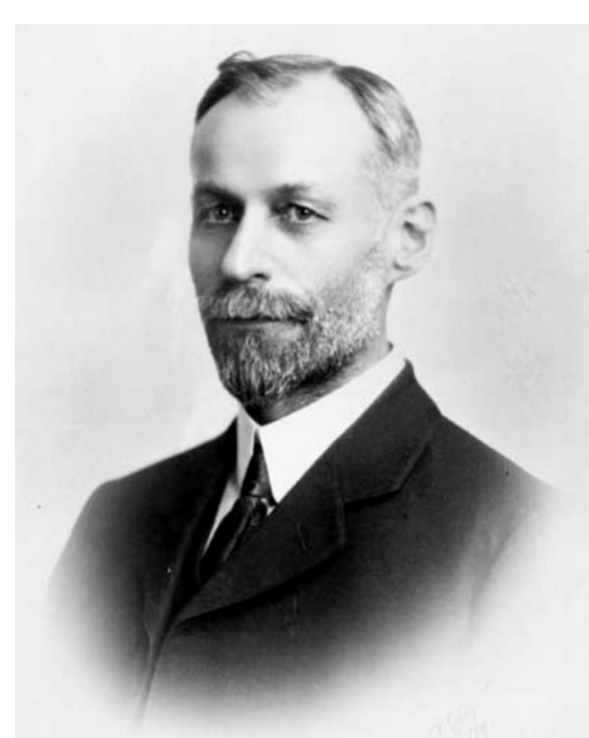

James Shaver Woodsworth after being elected Labour member of parliament for the federal riding of Winnipeg Centre in December 1921 (C-057365, Library and Archives Canada)

\section{FOREWORD BY THE PUBLISHERS ${ }^{1}$}

Prairie-bred, reared in a sheltered and cultured home; for years a Minister of the Gospel and close student of social problems, never having done for pay a day's manual work, the writer of these articles found himself, in 1918, attempting to earn a living as a longshoreman at Vancouver. His past unknown to his fellow-workers, he was able to learn conditions from the inside. In time he became a member of the International Longshoreman's Association Local 38-52 Auxiliary.

These articles, written at the time, give intimate glimpses of the life and thought of the labour men. It is hoped they may serve to interpret the viewpoint of labour and that their publication may stimulate an interest in our still unsolved industrial problems.

\section{COME ON IN - THE WATER'S FINE! \\ My Winnipeg friends who knew me in connection with church work or social service activities would probably hardly recognize a longshoreman in grey flannel shirt, overalls and slicker, who lines up with his gang alongside a ship or stands waiting in line for his money at the office of the stevedoring company. Yet it is}

\footnotetext{
${ }^{1}$ In terms of editing, minor changes to punctuation and wording have been made to improve readability. Anachronistic and prejudicial language has been updated to reflect modern sensibilities. The original intent of Woodsworth's writing, however, has been preserved as much as possible.
}

The Northern Mariner/Le marin du nord, XXVI, No. 1 (January 2016), 48-68 
the same J.S.W. who, though declared to be down and out, is in reality, feeling fairly fit and looking forward to the fight.

To some of my former associates who are apt to pity me as they stand shivering and uncertain on the shore, I would call back, "Come on in - the water's fine!"

Yes, I hesitated to make the plunge. Where a man has spent all his time up to middle life along one line it is not easy to make a complete break and as it were, start life all over again. But circumstances have a curious way of pushing one right up to the brink. Then, unless a man is a downright coward, it is a case of "Here Goes!" Some friends, with the kindest intentions, tried to dissuade me. "It would ruin my career." "But just think - a mere labouring man." "Then you should consider your wife and family."

And the water was cold - no doubt about that. Longshoring is hard and monotonous and irregular and, taking it the year round, no much better paid than other unskilled labour. Being a town-bred boy and having gone through school and college into professional life, I had never done manual work. Piling heavy rice sacks or stowing flour or loading salmon or trucking up a steep, slippery gangplank is no child's play. For one accustomed to congenial mental work in study or office or on platform or committee, it is doing time to go through the same dull mechanical exercise hour after hour, and day after day. Then to stand for three months on the street outside the Union Hall on the chance of getting a job and then after hard work and the strictest economy not to be able to earn sufficient to support the family, well, the water was decidedly chilly.

But once in, one has to make the best of it. No one sinks without a struggle and in the struggle the blood goes coursing through one's veins till the whole body is a tingle. Then, as one rises on a buoyant wave, he feels like shouting back: "Come on in - the water's fine."

As everyone knows, manual work means both a physical and mental stimulus. Undoubtedly hand development and brain development have gone on side by side. The attempt to divorce them is fatal. I believe that the worker, when not overtired, thinks straighter than the man in a sedentary occupation who rarely takes sufficient exercise. On some bright days when work is going with a swing and one can look beyond the ship's rigging across the blue inlet to the snow-capped mountains, one feels that life is worth living. Then, for me, there is a charm about life on the waterfront. The land fronts the mysterious ocean. Coasting boats from Alaska and from California, big liners from the Orient or Australia, transports from England or Siberia swing alongside the docks and unload their diverse cargoes which are soon on their way across the continent.

There is a certain exhilaration in having broken through artificial distinctions - in meeting men as men irrespective of nationality or creed or opinions - in being one of them. At lunch time a big motor dray started down the street; half a dozen workmen, like so many youngsters, climbed on for a ride. The driver wore the button of the teamsters union; we, that of the longshoremen. We were one - members of the glorious army of workers.

Perhaps it is, in part, because "he that is down need fear no fall" - that the workers have "nothing to lose but their chains" - but there is a certain sturdiness and fearlessness about the workers that is not commonly found among the so-called higher classes. At this time of social unrest, when many stand appalled at the uncertainties and dangers ahead, an old friend of mine whose life has been a hard one rubs his hands with satisfaction as he declares: "Things are looking pretty good for us." Another worker who had visited the Provincial Parliament buildings, and admired their beauty confessed, "You know, I couldn't but think that one of these days that would be our building." There is a strange thrill in being for better or worse one of us - one of the common people. 
How often have I thought of the phrase used concerning the Nazarene: "He became like unto his brethren." So much of our time seems to be spent in distinguishing ourselves from our brethren. Wealth, social position, academic titles, dress - all are used to set one above his brethren. Verily that kind of thing has its reward. But life has other and more satisfying rewards.

At present the odds seem against us. A minister in a Christian church is forced out of his church because he tries to be true to what seems to him the teaching of Jesus. A social service worker who has spent years in what he thought patriotic work, is dubbed unpatriotic, pro-German, Bolshevist. Possibly, as some of our friends tell us, we may have made a big blunder. Possibly we may yet be forced to yield. "The flesh is weak." But though muscles often ache and the back is tired and much is uncongenial there is more than compensation in being as yet no man's slave. And what if, after all, as we believe, we are right.

So after the first shock I have got my breath and shout back my message of good cheer: "Come on in - the water's fine!"

\section{AT THE BAY - ON THE SHORES OF THE LAST WEST}

The longshoremen of Vancouver are as varied in type as their previous occupation and place of residence. Predominantly composed of men from the British Isles, the union includes representatives of nearly every European country, a few Japanese, and odd individuals from South America or the Philippines.

The Canadians and Americans are usually of the frontiersman type - sons of frontiersmen. Their ancestors settled in the New England States or in Ontario. They were carried westward by successive tides of immigration to the Mississippi, or Minnesota; then to Montana or Alberta, and finally across the mountains. As soon as civilization has pressed upon them, they have hit the trail for new lands and new adventures. Now, thrown back from the Yukon, they drift from camp to camp or find temporary lodgment on the waterfront. For such men the war offered one more trail to the West.

Among the Britishers are men who have tried life in all the colonies in succession. The majority are mechanics who migrated to Eastern Canada. After a few months in Montreal, or Toronto, they passed to the prairies. They worked on a farm, or perhaps took up a homestead. Unable to get a start, and dissatisfied with the climate and rural life, they too crossed the mountains, and after unsuccessfully trying this, that and the other thing, have settled down to the casual work of dockers with a little garden and a few hens in Burnaby or South Vancouver.

Italians and Slavs, impelled by land hunger, or tempted by high wages, have left their old homes and associations to live as strangers in a strange land. Their fixed ambition has been to secure for their children better opportunities than they themselves have enjoyed. They have endured hardship and privation; they have been exploited and despised. The promised land, like the jobs to which they were sent, proved a sore disappointment. Men without a country, they find themselves in wartime marooned on the shores of the Pacific.

That rather stolid Englishman on the slings began life as a country lad. Economic pressure and ambition led him from the steady-going life of the farm to a small business in town. Too honest to resort to the unscrupulous methods of his competitors, he lost the savings of years. Perhaps it was his own fault. He would try again in the new land. He has tried, and after many years of faithful service is dependent at last on the possibilities of a chance job. 
His mate is a skilled mechanic. He began very successfully working on his farm. Then came the inevitable depression which swept away everything. Patiently he worked to retrieve his fortunes in Canada. Again the boom burst, leaving him without even a home. Ranching, mining, lumbering - what has he not tried? All blind alleys - providing at best, food, clothing and shelter; not always that. He is convinced of the hopelessness of individual effort.

The pleasant-faced youngish-looking fellow wheeling a truck is a skilled accountant. As a lad in Ireland he had a very fair education. Early he set out to see the world. Caught by a pair of brown eyes, he settled down into a family man. He knows the inner workings of commercial life - its selfishness and its graft. Thrown out of a position after years of service, he prefers the independent and not less remunerative life of a longshoreman.

The man behind him is a returned soldier. You notice the limp. Out of a job, ready for an adventure, stirred by martial music, he was among the first to enlist. He has returned disillusioned. "Never again," he says bitterly. "Now that the war is over they have no use for me - a pension of thirteen dollars a month. I'll get even with those officers yet - and those grafters and their millions - and yonder Chinks. We're just waiting till all the boys come home." And an ugly light came into the eyes of the limping trucker, who had gone over the top.

The hatchtender was born on the Clyde and ran away when a boy. He has sailed the seven seas. He knows countries and men. In foreign ports he has drained the cup to its dregs - yet he has never lost a certain self-respect - and for many a year, Ulysses-like, he was ever ready for a new voyage or a new search after satisfaction. But, now, youth is left behind. Seafaring has sadly degenerated. Half the crew are Chinese and Japanese. He is content with a less active life so long as he is within sight of a ship's rigging. But the old fires are not dead, and may yet flare up, and this time to some purpose.

That bunch of men rolling the oil barrels - one is an ex-minister. Years ago, in an ancient university, while engaged in historical studies, he broke away from the orthodox evangelical positions. He threw himself into all sorts of social service activities where, by slow degrees, he learned to trace the causes of social evils. Then came the war. Conventional religion and profiteering patriotism were seen in their true light. He preferred the rough and uncertain road of freedom and followed the great adventure over the mountains to the land's limit.

His companion is a young Greek. When but a child he fared forth to follow his ideal. In Egypt he moved out and in amongst the many throngs, picking up a smattering of half a dozen languages and meeting different views of life. The new world beckoned him. South America did not offer what he sought. He came to Canada. By slow stages he has crossed from the Atlantic to the Pacific. He has engaged in every conceivable occupation and learned, alas, that in no country can he live up to his ideals. Passionately devoted to his language, lighted by the wisdom of the ancient philosophers, he dreams of an international republic in which the idealized genius of Greece will find realization.

Together these two deliver their oil barrel to a big Finn. He had been through the fight for democracy in his own unhappy country. Years ago, when he emigrated to New York, he had given his scanty earnings to a Finnish professor to help start a Socialist newspaper. In California, he had been induced to join a co-operative colony on Malcolm Island. The scheme had failed. He will not travel further. The shores of the Pacific afford standing-room for one more struggle for democracy.

From the cradle of the race, civilization has moved westward. Ever there has always been an outlet to the West. But now the circle is complete. The West faces the East just across the Pacific. Men have fled before the system, but the system has overtaken them - it 
is crowding them into the sea. As they awaken to the situation they are preparing, with quiet determination, not to trek but to stand.

Curious passers-by look down from pier D on the group of roughly-dressed men that wait alongside for the pick. Patiently they wait. The gangs are picked. A hundred men, without work, move silently away.

Little do the passers-by realize the force that is silently gathering momentum. These men represent the great army of Labour. The war has carried us to the shore of the last West. We stand at bay.

\section{ADVENTUROUS SPORT ON THE WATERFRONT}

Most of us at some time in our career have experienced the thrills of looping the loop, or the exhilaration of bobsleigh coasting down a winding hillside road. But for genuinely adventurous sport give me the Grand Trunk slip on a low tide.

Little wonder that some of the dockmen are enthusiastic and expert mountaineers. It is strenuous work, when loaded with a heavy pack, to climb hour after hour up the lower slopes of some great mountain, but it is not less strenuous to climb hour after hour up the long, steep, slippery slip, pulling a heavy truck behind one. The great difference is that at the end of the latter, there is no view from the summit. On the Grand Trunk climb, it is in the descent that the fun comes in. At the bottom of the slip with its high side walls, are the sloping gangplanks leading to a strip of more or less flat deck beyond which in a direct line is an open elevator shaft with a sheer drop into the hold. It is decidedly interesting to negotiate this slope with a heavily loaded truck. Glissading down a glacier with transverse crevasses seems absolutely tame in comparison.

The expert cautiously cushions the truck down the upper slope - that is holds the truck half sideways with one wheel rubbing against the ship's curb, so that friction may lessen the velocity. Then comes the swift swerve to the right to catch the gangplank, the jolt over the loose toe-board, the attempt to cushion the gangplank, the running slide over a metal plate and the final triumphant swing to the left by which one avoids the yawning depths of the elevator shaft, and pulls up in good style on level ground.

Each trip adds unforeseen variation. A slip of the foot may precipitate a whole series of unforeseen events, in which the cases on the truck may take a very prominent, if erratic, part, as the load may shift, altering the balance, and rendering useless all calculations. Or, unable to see over a huge case, the trucker may fail to swing in time to strike the gangplank, in which case he strikes something else, sometimes with a holt that makes cuss words fly like sparks from an anvil.

Then ahead is another trucker, whom he doesn't want to telescope, and above and behind a very awkward-looking brother maintaining a precarious hold on a still more awkwardlooking truckload. The performance is not without its tense moments. Fortunately the men refuse to be speeded up. But with all care it is with a sense of relief that one arrives in safety at the bottom.

As the Asian described tobogganing, it is a case of "W-i-sh-sh-walkee back half a mile!"

But, in all seriousness, why should life and limb be risked and slavish work performed when the installing of modern equipment would bring conditions of work up to modern standards of safety and welfare.

An elevator costs money. A man can readily be replaced. Is the work of the Compensation Board limited to mopping up after the accident? 


\section{DO YOU LOOK AT YOUR WATCH?}

We are working on the slings - a big ship from China is discharging her cargo. Our hatch is rice - not the big two hundred and twenty-four pound sacks - that's heavy work. Only the hundred pound sacks. As the sling dumps these on the docks our business is to load them on the trucks. It is seven o'clock in the morning. The air is bracing. The sun sparkles on the water and lights up the mountains across the Inlet. My mate and I, each armed with a hook, reach for the first bag. How light it is. One - two - three - four - there is swing to things. The next trucker stands waiting. One - two - three - four - a break for a moment - one - two - three - four. "There's the Maccura," exclaims my mate as the big Australian boat swings into view at the end of the pier. One - two - three - four - a strange humming above us - we stop for a moment to watch a hydroplane circling overhead. Two truckers are waiting. One - two - three - four - "away you go." One - two - three - four - how hot the sun is getting. A big motor truck has blocked the line of trucks - we take a break for a minute into the shade of the shed. Then I looked at my watch - nine-thirty - half the morning gone. One two - three- four - the sacks were getting heavier, the sun beat mercilessly down. "Me no like heat," said my mate. "Me from mountains in Ecuador - snow on mountains. This like time I work in Panama - many men sick." One - two - three - four - the monotony of it all. A creaking of the winch and a rattle of chains and the great sling brought another load of sacks as from an in exhaustible mine. The truckers took them to the pilers who had already built a good sized step pyramid. One - two - three - four - again I looked at my watch - eleven o'clock. What about the dignity of labour? What about the opportunities for self-expression, for initiative, for artistic enjoyment? How that last hour did drag. Surely the bags were heavier. Thrown on carelessly, a whole truckload slipped to the floor. My mate uttered a curse and blamed the trucker. "Bracka you d********."

A vicious jerk of the hook and a small hole sends a stream of rice to the floor. "Why should we worry?" laughed the trucker. "Aren't the capitalists making their millions out of us? This new ship nearly paid for herself on the last voyage and yet the price of rice goes up."

Again my watch. "Ten minutes, boys." Ten minutes till noon and the respite of an hour and then again - one - two - three - four - another five hours and then perhaps overtime - then home too weary to wash up to go anywhere - too weary almost to tie up the tomatoes in the bit of garden. Tomorrow at it again by seven o'clock. "I hope we'll have hemp bales. They're heavier than the rice sack, but it will be a change anyway." "It's a relief," said a trucker "to go to another part of the shed." One - two - three - four - long hours, heavy work, monotony, no personal interest, merely a cash nexus, a rankling sense of injustice of the present system - why shouldn't I look at my watch?

Sir John Willison warns against the growth of Socialism, does not believe "that progress will appear except through individual initiative, that organized society cannot exist except upon the basis of private property - that the world will take its slow way to the uplands, reform will proceed by slow degrees, by more and more"; he declares "there is safety in sympathetic cooperation between employers and employees and wise recognition of the identity of interest between capital and labour."

Sir John's eloquence moves me not. One - two - three - four - Sir John fails to understand the workingman's psychology - Sir John still believes in the existing system. The workman has ceased to believe in it. 


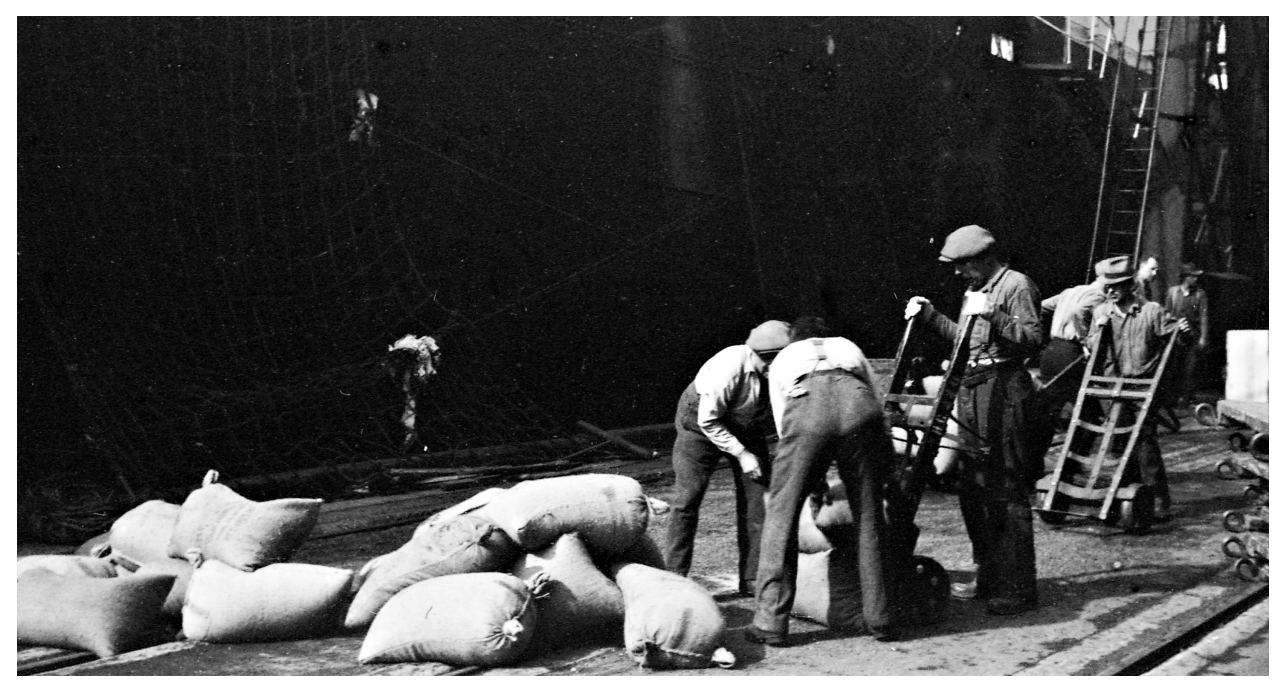

Longshoremen load sacks on the Vancouver waterfront (AM 640-S-1: CVA 260-317, City of Vancouver Archives)

\section{THE BEAUTY OF WORK - IDEAL AND ACTUAL}

"The pleasure which ought to go with the making of every piece of handicraft has for its basis the keen interest which every healthy man takes in healthy life, and is compounded, it seems to me, chiefly of three elements - variety, hope of creation, and the self-respect which comes from a sense of usefulness, to which must be added that mysterious bodily pleasure which goes with the deft exercise of the bodily powers," so said William Morris.

It is well sometimes to get a glimpse of what work might be and which, in the cooperative commonwealth, it will become. We know something of what William Morris is describing. When as boys, we dug into a huge snowdrift and made our castle, we experienced the joy and exhilaration of work. We dug the channel and carefully scooped out the miniature room and laid up our store of snowball ammunition and then rushed into the house all aglow to eat some of mother's doughnuts fresh from the pot. Ah, but that is play, and we were boys. And why should we so soon grow old? I think of a neat little cottage on a small farm. Two young people built it. The wife proudly showed me over the home. "Do you know," she said, "I think I held every board while Jack nailed it." How carefully the boards had been matched. That little corner cupboard had taken a lot of designing. How they had discussed the wainscotting of the dining room. The sink was not yet finished. They were waiting till Jack could find time to dam up the little creek. During two years these two had built themselves into the little home. It was for them a thing of beauty and a joy forever. Such work measures up to the standards given to us by Morris.

But what is the work most men are compelled to perform? Once I saw in a penitentiary a row of men seated on a long bench. In front of them was a long pile of stones. Each man wielding a hammer, bent over his task breaking the stones into smaller pieces. Up and down, up and down went the hammer, monotonously, hour after hour - no object, no interest, no change - killing time and killing the souls of the prisoners. They dared not straight up. They dared not stop work. They dared not speak to one another. Such is the punishment in 
Canada in the year of our Lord, 1918. No wonder there was a mad house in the corner of the penitentiary yard.

But is the lot of the free worker so much better? Watch him as he trucks salmon cases from the ship to the warehouse. Physically his lot is much superior to that of the convict. He is in the open air, not bending over a dusty stone pile. He can talk to his fellow workman. He eats in a restaurant instead of in a cell. He is to receive wages at the end of the day.

But is his work in itself so much more interesting? He shoves his truck to the sling. The loaders put on four cases - one - two - three - four. He brakes, throwing his truck into balance. Then across the shed he wheels his load. The pilers stand ready to receive it. He throws up the handles and by a deft movement withdraws the blade of the truck, leaving the four cases one on top of the other ready for the pilers. Then back he slowly wheels his truck to the sling - one - two - three - four. His load is ready. Across the shed again, a trucker ahead of him and a trucker behind him going through the same motions. Back and forward loaders to pilers - pilers to loaders. Is it any wonder he looks at his watch? Ten-thirty, the morning is half gone, anyway. Back and forward - loaders to pilers - pilers to loaders loaders to pilers - pilers to loaders. The pile of salmon cases grows slowly - it is twenty cases wide, twelve high, and before night will be twenty deep. Slowly tier by tier it grows. Back and forward - loaders to pilers - pilers to loaders - loaders to pilers - pilers to loaders. An odd case of half flats - it must be taken to another pile. The little journey is quite a relief we know so well all the knots in the floor in that backward and forward march between pilers and loaders. A false move and a case slips to the floor. The piler utters a savage curse. How irritable he becomes. Back and forward - loaders to pilers - pilers to loaders - loaders to pilers - pilers to loaders. "Twenty minutes," says a fellow trucker as he passes. He need not say more. Twenty minutes till noon - and freedom.

Then back again for another five hours - long, drawn-out hours - backward and forward pilers to loaders - loaders to pilers - pilers to loaders - loaders to pilers. "I've been on salmon trucking for four days - I'd be glad of a change to rice sacks," admitted the truckers. So it goes - day after day - and the days stretch into weeks and the weeks into indefinite years. Unlike the convict, the free worker can quit his job. Oh, but then his money stops. He has no free lodging and board as has his brother, the convict. So next morning, seven o'clock finds the worker standing in the drizzle outside the hiring hall waiting anxiously for a possible job. He is one of a hundred that stand patiently waiting. The secretary appears at the door. The hundred men crowd toward him. One man has had no work for three days; another has a sick wife and must take every job that offers; a third is saving so that he can have a long-deferred operation that may possibly save his sight. "Brown, Jones, Martelli, Tolski - Eastholm - Evans - Coleman," calls the secretary, and the four men move off to unload the Eastholm at the Evans, Coleman, and Evans dock, leaving ninety-six disappointed men standing in the drizzle.

"Variety in work." What variety in the weary march trucking salmon cases - or doing the single piece of monotonous work that is the day's work for so many today.

"Self-respect, which comes from a sense of usefulness." What usefulness in building mountains of salmon cases that are being loaded into vans even before we finish the last tier? What usefulness in perpetuating a wasteful system of competition? "If we can make the work last another hour we'll get six bucks on the job." Why not? We can't afford to buy these little salmon tins that we are piling mountains high and yet know fortunes are being made out of them.

"Hope of creation." It is to laugh! We notice an improvement that could be made curse for your pains. "That's up to the boss." 
"Mysterious bodily pleasure which goes with the deft exercise of bodily powers." Backward and forward - loaders to pilers - pilers to loaders - loaders to pilers - pilers to loaders. Three minutes to six o'clock our coats are on. "Back at seven o'clock, boys," says the foreman - and wearily we trudge homeward.

Is it any wonder that the worker dreams of a six hour day - and beyond that of a new social order - when he can live a man's life and do a man's work?

\section{THE TRAGEDY OF WAITING FOR A JOB}

A hundred men stand on the street in front of the Auxiliary hall on Cordova Street. It is eight o'clock on a foggy morning in October. They are waiting for a possible job. The Longshoremen proper have the preference. If there is a rush, the orders for men are turned over to the Auxiliary. In normal times, the members of the Auxiliary Union are able to handle the work. If several large boats come in at once they must secure outside help. The waterfront has been unusually active. So men laid off from the shipyards, or who have drifted in from the camps, have been picking up short jobs at good wages per hour. But for a week now, things have been quiet. The Longshoremen are working coast boats which when work is plentiful, they will not touch. The hall is full of men hungry for work - like wolves after an enforced fast. So the men on the outside stand waiting.

How patiently they wait. They have been waiting since seven o'clock. They will wait all morning. Some of them will be back in the afternoon. Some will wait on the chance of a night job. They waited all day yesterday in the rain. Day after day they have been waiting for a week past.

Is it a good job that makes them wait so patiently? Sixty-five cents an hour usually, with ninety cents for overtime. That sounds like big money and at present men on the waterfront probably receive more than unskilled labourers anywhere else. Some of them think themselves lucky when the job lasts twelve or fourteen hours! A few of them on special occasions have worked without sleep for two or three shifts. Are they greedy for money? No, but they were trying to make hay while the sun shone. They knew the rainy days were coming. One of the steady men in the Union found that last winter his earnings averaged $\$ 21$ a week.

But why don't they look somewhere else for a job? Where, we ask, will they go? What work is there in Vancouver? There are the shipyards. Here is a man who was working in the shipyards, working for $\$ 3.85$ and then was laid off when the yards shut down for lack of material. In the three months he had been on the waterfront he had done better than he had in the shipyards. Besides the shipyards were not taking on any more men. So he was waiting.

Well, they can go out to the camps. Yes, many of them will be forced to do so. The married men don't like to leave their homes, they can't take their families away from school, and in the camp there is no accommodation but the bunkhouse. There is a strong looking fellow that might go. Ah, he has been in the camps for years. He was eight months at Anyox. He stuck it out as long as he could, but at last the gas was too much for him. Since he left, his mate had lost his leg - slipped into a bucket of liquid copper. So he, with the married men, is waiting.

But surely they can get something. Yes, there are some jobs in which they can get thirty or forty cents an hour, but how can a man keep a family on that? They have struggled to do it for years. Some of them are painters. Painting is hard work and dangerous. Then there isn't much doing in the painting trade at this season. Some of them have been teamsters - one 
man hasn't been at it since that long spell of pneumonia. Some have had little ranches, but the Chinese took the profits out of that. So they are waiting.

These men are not lazy - not more lazy than other men. There are, it is true, a few interesting men who have seen much of the world and who have adopted a philosophy of life that will not permit anyone to drive them too hard. "I like this better than a regular job," said one, "because I can take a holiday when I like." In regular work you must be down at seven o'clock every morning in the week, week in and week out. If you miss a day it's the devil to pay. "Now here," he concluded laughingly, "I've been off for a week and no one asked any questions." Another is quite satisfied if he gets enough to keep him going.

If he gets his meals and tobacco, why should he worry? But there's something more here. "Why should I take the work from someone else? There are many poor married devils here who are doing their best to provide for the wife and kids. I would rather give them a chance." Yes, most men in that crowd are poor married devils putting up a brave fight. So even though the rain soaks through they must wait.

Nor are these men illiterate, shiftless, incompetent. They are well-read, many of them better read than the average businessman. Some of them are skilled tradesmen. Many have been in business. A few have had professional training. They have had experience in England, in the United States, in New Zealand, in India, in almost every part of the world. They have held positions of responsibility. Then why are they here? For many a reason. One made a wrong move; another had a run of bad luck, a fire, sickness in the home, business depression, bankruptcy; another staked years of savings on what seemed a good proposition. He lost; and, his competitor won. Another was not prepared to resort to the methods which seemed necessary to bring success. Another attempted too raw a deal and was caught. Education, thrift and ability do not decide whether or not a man is out of a job.

These hundred men who stand on the street, who have had such varied experiences, have one thing in common. They are radicals in their thinking. Possibly this is so because "they have nothing to lose but their chains." Possibly it is because they have been able to shake off the bonds of conventional thinking and conventional morality. In any case, on that curb stone in the foggy morning, you will find more understanding of the fundamental principles of economics than is found in most of our Boards of Trade or can be discovered with the naked eye in most of our legislative halls. These men have been up against the hard realities of life. They know what they are talking about. They have felt the dead weight of the system. They have tried in vain for years to escape from the net. They have learned their individual helplessness. They dream of the day when the common people will rise in their united might to smash the system which is responsible for the conditions under which they must live and work.

In the meantime they stand in the street waiting - waiting for a day's work.

Oh, the waste of it all? So much work in the world to be done. Yet, here a hundred men stand idle.

We write volumes on conservation, and yet raise not even a little finger to conserve and utilize the human brain power and hand power that is being worse than wasted.

We have to go to absurd lengths to save bacon on Wednesday, and sugar on Friday, while all the time we disregard the possibilities of developing our natural resources, so that there may be bacon and sugar, ad libitum, for all.

Ability of all kinds, ability and passionate love of farm life; ability and artistic skill in construction; ability in organizing men and handling goods; ability to carry forward a cooperative enterprise - such ability, for lack of a chance, stands on the street in the fog of an October morning, waiting for a job. 
Why stand you idle? They reply, "No one has hired us." There you have the difficulty. Others than themselves control all the jobs - control all the ways of making a living - control all the avenues of escape. They must wait the pleasure of others. These others, at war themselves; afraid, themselves, of falling by the wayside; forced to hire in the lowest market and to fire as soon as the job is done. What can they do but leave the men stand waiting?

Five men wanted. A hundred press forward. The five selected men move off rather shamefacedly. Ninety-five fall back again. "Lucky boys," cheerfully shouts one after them. "Stands in with the officials," mutters a second. "I wouldn't mind except for the kids," says a third. wait?

Ten o'clock and ninety-five men stand patiently waiting for a job. How long will they

\section{CAN'T GET AHEAD OF THE GAME}

"I've tried almost everything but do my best I can't get ahead of the game." So declared a worker as he reviewed his years of effort and failure. In that brief sentence, he summed up not merely his own experiences but the experience of the great majority of the working class.

In this country the idea that every man has a chance, that if a man fails it is his own fault, has been so instilled into us, that if we fail at one thing we try again, and yet again. The man who has failed on a little ranch in the country finds a job in the city; the man who has failed in a trade is often induced to see if he cannot become independent as a farmer. Of course a few individuals are fortunate and are able to rise out of their class. But the class remains down - perhaps lower down - because of the rise. Slowly it is being borne in upon the workers that something is fundamentally wrong - that whichever way they turn they are faced by a system which bars their progress.

Some of the workers are addicted to drink. Some gamble, some are lazy, but the most careful students confess that individual failing accounts for a very small portion of our social evils.

Take the question of unemployment which is again becoming serious. The majority of men are not idle because they will not work, but because they cannot get work.

Under present conditions a man is really barred from work. He would like to farm, but he finds that farm lands anywhere near the railroad are claimed as private. If he buys machinery he mortgages his crop to the machine man. When he sells his produce the railroad charges him all that the traffic will bear - that is up to the point at which if they went further the man would throw up the farm. So our farmer finds himself up against a powerful and relentless system. He has, of course, a certain margin to work on, and by dint of hard work and good management, may get a bit ahead. But this is becoming increasingly difficult.

Suppose our man wants to cut timber, Again he is barred. The timber limits are controlled by the big corporations. He may perhaps lease a few acres. Again rentals and interest and transportation charges. So with mining.

If he resorts even to the most primitive manner of obtaining a livelihood - hunting and fishing, he will find that he is debarred by a license and closed seasons and all sorts of regulations nicely adjusted to enable him barely to eke out an existence.

If he should attempt to go into modern industry, he finds himself helpless without capital. $\mathrm{He}$ is in competition with unlimited capital. Suppose he tries to start in a small way, say, to make shoes, he soon finds that he is dependent even for the leather on the wholesale firms that will not sell to those outside the trade, or will sell only at rates that make it impossible 
for him to compete with larger firms. Then if he should get the shoes made he finds the market so controlled that he is helpless.

If he starts a little business he soon finds that he is little more than an agent of the big concerns. The system is everywhere. Little wonder that the ordinary man can't get ahead of the game.

Yet this conclusion need not lead to hopeless despair. It may be the beginning of better things. We live in a social age, an age of social production. We have not yet learned that social production inevitably involves social ownership and control. Private ownership of the world's limited natural resources means monopoly. These natural treasures must again be open to the people. Private ownership of the great public franchises means that the people are disenfranchised. Public services must be available for the welfare of the people, not as a source of private gain. It is as hopeless for us as individuals to fight a world organization, as it would be for a savage armed only with bows and arrows to fight an army with modern artillery. Individual action is an anachronism. We must have united action. We must organize. We must control the system that crowds us back and keeps us down. Then and only then will the workers "get ahead of the game."

\section{INSPIRATION IN A WASHTUB}

The wife of a longshoreman was offering a constructive suggestion. "I thought of it," she said, "when I was at the washtub. That's where I generally get my inspirations."

Inspiration in a washtub - a rather novel suggestion. Yet why not? What more likely place?

Inspiration has become a rather serious word, carrying with it an odour of sanctity, connoting, as the logicians say, bibles and pulpits, and visions and angels. Thus it is quite conceivable that inspiration might come to some holy hermit as he performed his lonely vigils in a cave in the desert. Or an inspiration might come to some consecrated virgin as she knelt before her snow-white bed. But inspiration in a wash-tub in Vancouver in the year of our Lord 1918 - preposterous!

But as a matter of fact all down through the world's history inspirations have not come to men and women who sought them after the manner approved by our legend weavers. They have come to men and women in real life. Thomas Edison may be a modern wizard, but Edison did not make his discoveries by making secret passes or muttering mysterious formulae. The discovery may have come in a flash. We don't know much about psychological processes. But it came to a man who had given years of special training and spent long nights in labourious research.

After all, even in the history of religious thought, inspirations did not come to men who withdrew from the actual world and waited for special revelation. Moses, it is true, was in the wilderness when he saw the bush that burned but not consumed - whatever that bit of symbolism meant. But Moses was at his ordinary work as a shepherd. Our modern professional religious leaders withdraw into their studies and work hard enough - but though they pump and pump the water won't come, or when something does come the people don't recognize it as the water of life, and refuse to drink it. After all, religion is simply a knowledge of the true principles of living and such knowledge cannot come apart from real life.

Under the existing industrial system there tends to be a division between hand workers and brain workers. The hand workers are supposed to do mechanically what they are told. The brain workers are supposed to direct policies. But physiologists and psychologists alike 
tell us there is a very immediate and vital connection between hand and brain. Possibly in the evolution of humankind hand work has much to do with brain development. It is not an unlikely thing that if hand work were to cease the brain might become atrophied or at least altered greatly in its structure and function.

Of course, in practice, hand work and brain work are never absolutely divorced. The hand worker thinks - if not about his work then about other things. The one who probably suffers most is the so-called brain worker, who, so far as his work is concerned, is often out of touch with the actual conditions of the lives that he is supposed to direct. Is it any wonder that the policies he initiates often fail to work? Yet it is to him - the professional leader - that we generally look for inspirations.

Let us look at these two women. There is the one - a busy mother bending over a washtub. Here is the other - a society woman, childless, but a member of half a dozen clubs and patriotic organizations. To which of them should we look for leadership? Who knows the most about life? To whom are inspirations most likely to come? After all, this inspiration in a wash-tub isn't the preposterous thing it seems at first sight. It is quite conceivable that the society woman might have an inspiration with regard to some finishing touch to this evening's toilette, or the colour schemes for the next bridge party, or the shape of the boxes for the Red Cross tag day. But when it comes to an inspiration with regard to the really worthwhile things of life, I will back the Madonna of the washtub.

Out of the washtub are coming the dreams of a new social order in which wash day will not be the backbreaking, nerve-wrecking day it is now. Electric power in abundance is available in Vancouver. If our water powers could be in the possession of the people, who should really own them, an electrically-driven machine would lighten the labours of wash day and make cool and pleasant the labours of ironing day and make dustless and easy the labours of sweeping day - and our thoughts go to the hundred and one labour-saving devices that are already on the market - if only we had the money. And the woman turns her back to her washtub, but she has dreamed her dream and one day her dream will come true. Has she not a voice in the government? Cannot the government which alienated the public water powers reclaim them?

Women have rightly been rather suspicious when consoled for their lack of political power by the thought that "the hand that rocks the cradle rules the world." They are just beginning to realize that hands in the soap suds may make this country a decent place in which to live.

Out of the washtub are coming a new set of values. That little dress is Mary's, and Mary is going to school, and the mother dreams of Mary and her education. Like another mother of ancient time, she ponders all these things in her heart. She thinks of Mary's future - of her possible marriage - of the position of women under existing laws - of the shame of much of our conventional morality. Those pants are Jack's. She stops to take out of a bulging pocket a miscellaneous collection of strings and marbles, and cores and tin soldiers. Tin soldiers my boy, to go to war! My boy to come home broken like so many of the poor fellows - if he comes at all. What does the woman of the washtub care about the maintenance of some ancient dynasty, or the successes of secret diplomacy or the securing of new world markets. She loves her wee laddie. From force of habit she may join in "God Save the King" but her prayer is more truly expressed in "God Save the People."

Yes, out of the washtub is coming an ever widening sympathy - the spirit of the new brotherhood. As the mother thinks of Mary and Jack, she thinks of the little neighbour children - of Mrs. Brunn's struggle to get boots for her children to start to school; of the little woman next door, who should have an operation but whose husband can't get work because 
he came from Germany at the age of two. Of the thousands of little children all over the world who are perishing; of the thousands who are being nurtured in hatred - and the old Christmas message: "Peace, goodwill" - has a new meaning. The new movement has already begun.

Again the woman bends over her washboard, but not in despair. She has seen a vision and dreamed a dream.

\section{A SABBATH DAY MEDITATION}

Various circumstances are conducive to meditation. One may, like Harry Lauder, lie between the sheets on a Sunday morning while the smell of coffee comes floating upwards, and his meditation may be sweet.

Or after a Sunday dinner of substantial proportions and goodly variety, one may feel very much at peace with the world, and with easy chair and book and pipe indulge in very comfortable and comforting meditation.

In the good old days of long ago, when, on Sunday, everyone went up to the House of the Lord, it was a pleasure to join with the multitude that kept holy day. We sang "O day of rest and gladness." "No mortal cares disturbed my breast." Dressed in our Sunday clothes, surrounded by friendly faces, a comfortable home awaiting our return, life with all its alluring possibilities ahead, with hope quickened and soul strengthened by the service of music and exhortation and prayer - who has not experienced a time of pleasurable and, as we thought, profitable meditation?

But there are other and less pleasant experiences that lead to meditation. To turn reluctantly out of bed before daybreak on a winter's morning, to snatch a bit of breakfast, to walk a mile to work because the streetcars do not run early on Sundays, to stand all day long in the rain on the slings, or with stiff hands wheel a heavy truck back and forward for hours over an uneven floor, to eat with unwashed hands at a cheap restaurant - then is the time to mediate. In fact, such circumstances make one furiously to think.

Why work on Sunday? Simply because the work during the week has not brought in sufficient money to support the family for a week and Sunday work is paid as time and a half. But one should not work on Sunday - so the boss believes. He will not even walk to church; he rides in his private car - "Remember the Sabbath day to keep it holy." He joins in the response "Lord, have mercy upon us and incline our hearts to keep Thy law." But his firm keeps its plant in operation every day in the week. He drops a coin into the collection for the poor. Whose coin? Do I receive all that I produce? Surely it pays someone to keep me working on Sundays, even at time and a half rates. He goes home to his wife and family and music and friends. I work on in the rain out of hearing even of the church bells.

The church - a class institution - what does the church do to help me and those like me? The church supported by the wealthy - yes, "he who pays the piper calls the tune." That wellgroomed parson with his soft tones prophesying smooth things - well, I'm glad I'm not in his shoes.

But surely aside from its religious sanctions every man is entitled to one day in seven as a day of rest and recreation. So affirm the good people who support the Lord's Day Alliance. That is why they persecute or prosecute the little corner stores that sell fruit on Sunday. But what about the milkman who long before daylight starts out on his rounds to bring fresh milk for the breakfast coffee and the children's porridge? Has he a day of rest? What about the big industries that work eleven and thirteen hour shifts the year round. Why are they not 
prosecuted? The law, too, is a class institution. And is morality merely a class code and religion a superstition to keep the masses in subjection?

And why cannot I make enough during the week without working on Sundays? Our ancestors had numerous holidays. Even without the aid of machinery they produced enough and to spare. Here am I working like a draught animal, slaving under the eye of the foreman and all for the merest subsistence - didn't that Socialist speaker say the wage slave got only food, clothing and shelter - only enough to keep and reproduce himself? He was right. No, he was wrong - the wife has to go out working. We have to take Jack out of school. In this country the unskilled labourers - that is, most of us - don't get enough to support a family in decency.

Should a man marry and rear children to make profits for the boss? That's the question that the Socialist speaker asked us. The preacher in the bosses' church says it is wrong to go to the "red light" district. But can you blame a fellow who can never have a home of his own? After all isn't most crime the result of social injustice? In the big graft game, who is the criminal anyhow?

Sabbath day meditations. Not pleasant, not comforting. But they are shaking us free from conventionalities. They are opening to us new avenues of thought, new conceptions of justice, new ideals of morality. Who will say that they are less worthy than the meditations of our youthful days?

Ye that old time happy Sunday - why is it not still possible for us all?

\section{CHRISTMAS ORANGES AND CLASS ETHICS}

A cargo of Japanese oranges was being unloaded from an Oriental liner and as quickly as possible placed in cars to be rushed to prairie points in time for the Christmas trade. In the transfer from the ship's hold to the dock and from the dock to the cars a number of cases were broken open, some accidentally, some carelessly, some intentionally. The little golden balls frequently rolled to the floor under the feet of the men and horses. The freight handlers had a chance to quench their thirst and enjoy Christmas oranges before they came on the market - and all without money and without price.

It was a Sunday morning. The good eastern church people must have their oranges in time for Christmas, even though it means Sunday work for scores of men. But then these men need work, and Sunday work is paid at overtime rates, so we should worry. Perhaps it was the deserted streets on Sunday morning as we walked to work that a train of moralizing but these little Japanese oranges opened up the whole question of class ethics.

Thou shall not steal. Was it stealing to eat an orange picked from the floor where a minute later it would have been crushed under the wheels of a truck? Surely a man would need to stand so straight that he would lean backwards to hold that view. Was it wrong to slip the orange into one's pocket and save it for the kids who otherwise might have no Christmas orange? It seemed mean to eat it instead of saving it for the kiddies. And what about slipping a few out of a case which, in its damaged condition, would never reach its destination? But why, then, throw the skins out of sight or pocket the oranges when the policeman's back was turned? If it is not right to muzzle the ox that treads out the corn, is it right for the company to prevent the workers eating a few oranges out of a shipload?

Many considerations complicate the question. We were working recently on a cargo of five thousand sacks of peas. From a torn sack a stream of peas fell to the floor. The peas would cost us fifteen cents a pound. Ten pounds lay in a little heap. A man quickly produced a cotton bag and scooped up some pounds with his hands. In a few minutes, 
Chinese workers swept up the remainder with the dust and manure from the floor. A barrowload of wasted peas. What about food conservation? It was a shame to see such waste. Which was the higher duty, to save the food or to obey an arbitrary regulation? Of course, the officials could not tell which peas had been taken from a sack and which picked from the floor, but that practical consideration need not deter the practical worker who carries off a sack under his slicker. Law is not always right and it is the ethics of the situation that we are discussing.

On another occasion from a damaged tea chest an employee shook out a pocketful of tea. From a whole warehouse full why might he not have a few pounds? Stealing? Yes. But he justifies himself. The employer took the sweepings from the floor and sold them as "Brown's Best." Why should he pay forty cents a pound for sweepings? Another firm where he worked sold twenty cent tea for sixty cents. The head of the firm was a church leader and one of the most public spirited citizens. In another firm, fifty pounds of dairy butter with the addition of substitutes was regularly transformed into one hundred and ten pounds of creamery butter. If the law allowed the big man to steal from the consumers on a wholesale scale, why shouldn't the employee take advantage of his opportunities to pinch a few pounds of tea?

But, two wrongs do not make a right. True, but moralists tell us that rights and duties correspond. Has the big corporation for which I work any right to make profits of millions, and pay me only a pittance? A few tins of salmon help out the family budget in these days when the cost of living is so high. The big companies are making fortunes where they can sell the whole pack, good and bad, to the government and maintain monopoly prices. Who is the thief?

But the law? What of it? You remember the day the boys stole the smuggled whiskey from the Chinese merchant? If one of them had been caught with a pint he would have received a big fine or a jail sentence. But Findlay and the big gang can handle carloads. Don't talk to us about the law.

After all, is not theft a relative term? The Spartans taught their children to steal from their enemies. That was a highly honourable achievement. In war, it is considered quite right to take from the enemy whenever there is a chance. It helps us and weakens the enemy. Now the class war is more fundamental than a national war. Why should not the working class take all they can from the capitalist? So reasons many a class-conscious Socialist. When supply ships arrive in Siberia, it is said some cases will be empty. When the soldiers on guard tell the workmen to "go to it," it is fairly good evidence that the workers and soldiers have more in common than the soldiers and those whose interests they are supposed to represent. If it was right to spoil the Egyptian or to spoil the Germans, why not spoil the big interests who are seeking to spoil defenceless Russia?

The ethical question is not so simple as might appear. The rolling Japanese oranges have led us far afield.

Is it merely bourgeois training that restrains us from appropriating what lies near at hand? Then the same bourgeois training must keep us loyal to the members of our group. The policeman can catch the thieves; that is his job. Class law and conventional morality are being weighed in the balance and found wanting. Prohibition will not suffice. We need a new conception of life and a new social order. Among our native tribes one did not steal from another. When he had need he took and the other gave. It is under so-called civilization, with its institution of private property, with its keen competition, with its callous disregard for human welfare, that stealing has developed. Stealing is a symptom of deepseated social disease. The attempt to prevent a sore from discharging pus is about as 
reasonable as, under our existing system, to command: "Thou shall not steal." When society becomes a big family, the little chap will not need to steal a morsel from his big brother. There will be enough for all and to spare.

And the preachers wonder why they cannot reach the labour man.

\section{IF I DON'T, SOMEONE ELSE WILL!}

Big money was being paid for loading bombs to be used against the Bolsheviks in Siberia. The Longshoremen had passed a resolution of sympathy with the Russian Revolutionaries, but refused to quit work on the ground that, if they did, either the Seattle Local or the soldiers would be given the job. This context informed the following article.

"If I don't, someone else will." No expression is more commonly heard. It sounds plausible. But after all, it is a pretty poor excuse.

The thief sees his chance, "If I don't, someone else will," and he steals from the members of his own class. The man who preys on human weaknesses spies his victim; "If I don't, someone else will," and he takes cowardly advantage of the man who cannot resist.

The excuse will cover the worst crime or the meanest action under heaven.

It really means that the lowest standard of action is taken as my standard. Because, somewhere, someone is low enough to do a piece of dirty work, I might as well do it myself. Surely, when he comes to think of it, no man who has any respect for himself will take that attitude.

The excuse might serve in scab ethics. The organization may be one hundred percent perfect but always there are a few black sheep, a few Judases. If we went on the principle that we might as well sell out, or that we might as well scab, or "if we didn't, someone else would," where would our working class organizations be today?

As a matter of fact, the thing is not true. The other fellows are as honourable as I am. It ought often to be, "If I don't, nobody else will." By my cowardly or selfish attitude, I am holding up the whole works.

Progress is made when someone has courage enough to say, "The others can do as they please, I'm going to do the right thing anyway."

Strangely enough others are thinking much the same way, and, sooner or later the small minority becomes a majority and the new line of action becomes the accepted policy.

All of which train of thought was suggested as one of the reasons given for the longshoremen handling ammunition for Siberia. There may be good and sufficient reasons why the longshoremen should continue to do their bit in fighting the Bolsheviks, but I submit that this is not one of them. There is a decided suspicion that sympathy for the Bolsheviks does not go as deep as the pocket. It is hard to give up big money.

"If I don't, someone else will" - so it is no use for me to refuse to handle the stuff unless the union decides not to do so.

"If we don't, someone else will" - the soldiers perhaps - yet many of the soldiers have refused to go to Siberia. Surely the least we can is to back them up by refusing to send on ammunition.

"If we don't, someone else will" - Seattle, for instance. It is no use our taking action till all the unions in the district act. Is that the principle on which the One Big Union is being advocated: Decidedly not! We are urged to act independently, and in the hope that our action will stimulate others to action.

Surely we are not going to let somebody else do all the fighting, take all the risks and make all the sacrifices, and calculate to come in at the time to join in the shouting. 
If we are not prepared to stand by them, do not let us pass any more pious resolutions of sympathy with the Bolsheviks. We are accusing the church people of sending guns and Bibles to the heathen; do not let us send guns and resolutions to Siberia. Let us cut out one or the other.

\section{THE RISING TIDE OF DEMOCRACY}

A group of warehousemen were sitting around at lunch hour. "They talk of scarcity of food," began one man. "I was through *****'s warehouse yesterday - the extra one they have rented. It was piled high - all kinds of goods. They had to move a carload of potatoes to make room for more salmon. The potatoes had been kept there till they were rotten. A shame to see spuds wasted like that."

"That's nothing," said another, "last year I worked down near False Creek. The whole place was stinking with rotten onions. They had dumped carloads of them. You remember how high a price onions were, too, at that time."

"You see," chimed in another, "some of those who stand in well take the stuff to the incinerator; others are afraid to do that. This Spring I saw hundreds of cases of eggs from ***** burned in an open lot, and you remember, Mac, (turning to his mate) all those oranges that were dumped into the woods out our way."

"There ought to be an investigation," remarked an Old Countryman. "Investigation be damned," exclaimed number three. "They are all in the same bunch. A few things come out. Some little fellow is the goat. Things quiet down and everything goes on as usual."

"Well, if I could write like some of these guys," said Mac, "I would write a letter to the papers." There was a chorus of derisive laughter. "They would not pay any attention. Lots of people write and it does not do any good." "The capitalist papers would not publish it," said number three, who frequented Socialist meetings. "They depend on their ads and they dare not go against the businessmen. They are all a part of the same rotten system."

A quite man in the corner contributed his bit. "Even the working class papers won't publish the worst. They can't. During wartimes, the bosses have it all their own way. The censor can stop anything he likes, or the paper must shut up shop. Patriotism covers a multitude of sins. That Union government is just a big bunch of grafters."

They sat smoking in silence for a few moments.

Then the quiet man, taking his pipe from his lips, began: "It is about time somebody did something. We sit here day after day chewing the rag, but things are getting worse all the time. We have got a job today, but, if things go slack, where will we get off at? They talk about lots of work, but where is it? Nothing much outside the shipyards, and there plenty of men get only eighty-five cents, and then are laid off for weeks at a time. If the shipyards close down, what then? Of course, there are the camps. You can get about $\$ 4.50$ or $\$ 5.00$, with $\$ 1.50$ for board, and there is no way to spend your money - work and go to your bunk. You are better off than in town, but a man does not want to be away from his family all the time. What it will be like when the war stops, God only knows."

Here the Socialist interrupted: "I tell you all this means things are looking pretty good for us. People won't learn till they are starved. You remember how it was in Vancouver before the war. Things will be ten times worse. They have been fed up on a whole lot of patriotic stuff till they half believe it, but it is getting through their heads that if they were good enough to fight for their country they are not going to let the grafters have it all their own way. The revolution is coming and there will be a hell of a time. The capitalists won't give up without a fight, and they own the government and the army." 
This was too much for the Old Countryman: "This is not Russia - we do not need to get out our hooks and start out to kill somebody. Besides, it is no use. The government will have an army at it's back. I tell you we have got to get hold of the government like they are planning to do in England. We can elect our own representatives to parliament."

Here the quiet man saw his chance again: "That is just what I was getting at. But somebody's got to start something. Do you think the Canadian Pacific Railway or the other big fellows are going to change things? Not much. And the Government - Jack is right when he says the government is owned by the capitalists. No, we have got to do this thing ourselves. But I want to know when we are going to get busy."

The whistle blew and the men moved off.

Wherever working men meet they are talking political and social and economic change. The quiet man thought somebody ought to start something. Something has already started a mighty mass movement is slowly gathering momentum. It is not the outcome of organized propaganda; it is not the work of imported agitators; it is not financed by German gold. It is a movement of the people, for the people, by the people.

When will the revolution begin? It has already begun - where all revolutions begin - in the minds and consciences of the people.

I wish I could speak a word that would reach inner consciousness of our so-called intellectual and religious and political leaders. They are not the hypocrites, the sinecureloving exploiters that many imagine. But they are bound by a class consciousness, the narrow limits of which few of them recognize. They are the beneficiaries of a system which, though they do not fully realize it, is founded on injustice and is ruining the homes of millions. Though they think themselves moral and religious, they grope in the dim light of an individualistic creed from which the common people have escaped into the broad daylight of God's out of doors.

Much depends upon these leaders. They cannot be leaders in the new movement unless they too gain the social conscience, renounce their special privileges, and become in spirit "like unto their brethren." They cannot be leaders in the new movement, but they can do much to determine the character of the movement. They may dam it back by repressive measures till it breaks through in a devastating flood. They may repeat the old game of fostering national and religious prejudices and so for a time divide and conquer the opposing forces. But this is an increasingly dangerous, and, at best, only a temporary expedient. They may appeal to the selfish interests and ambitions of individuals or groups. This may delay the forward march, but new and more determined leaders will be shoved to the front, and the rank and file, betrayed and embittered will be in no mood to give quarter or adopt the moderate measures which will then seem so desirable to those who have stood in the way of progress.

The tide is rising. Who can bid it stay?

\section{THE BUSINESSMAN'S PSYCHOLOGY}

A good deal of nonsense is often solemnly uttered by Socialist speakers and other working class advocates with regard to the capitalist bunch. They are classified as bourgeois and petit bourgeois. They are often depicted as a set of self-conscious hypocrites. Frequently highly-coloured pictures are drawn of the idleness and luxury in which they live.

Now, as a matter of fact, most of these descriptions are secondhand, being borrowed from translations of European writers, some of them writing of conditions which existed 
thirty or forty years ago. Certain distinctions are considered essential to the maintenance of orthodox scientific theories of social development.

We submit that there is nothing to be gained by maintaining arbitrary or erroneous ideas. We have, for example, in America no class corresponding to the bourgeois class of Europe. Our middle class occupies a very different position from what in Europe is known as the middle class. Most of our wealthy men have not inherited their wealth and by no means live an idle, self-indulgent life. They are, according to their lights, highly estimable citizens.

The rather crude invective with which these capitalists are assailed has not only the effect of making their minds to a still greater degree impervious to modern social ideals, but it also prevents the workers understanding the true position of those whom they regard as the enemy and hence adopting the most effective form of attack. Not infrequently the members of the business and professional classes are as much the victims of the system as the manual workers who have become class conscious.

In the background of the minds of the majority of the successful businessmen of Canada there is an old Eastern homestead. The successful businessman may lunch at a high class club or occupy a box at the theatre or spend his vacations in Europe, but as a boy he did the chores, swam in the village millpond, cut his name in the desks of the little red schoolhouse, and generally lived the all-round democratic life of a farmer boy.

Those who have come to Canada in recent years, especially to Western Canada, often fail to understand the Canadian life of a generation ago, in which the men past middle life were nurtured. Agriculture was the predominant industry. There were few cities, and these were small. Social problems were unknown. The virtues and vices were those of a simple individualistic type of society.

The labour problem was confined to the hired man and the hired girl, but as there was plenty of free land, the hired man soon took up land for himself. As there was a scarcity of women, the hired girl soon found herself in a home of her own.

Flitting recollections of such a life pass before the half-shut eyes of the big business manager as he rests in his comfortable leather chair after a heavy day at the office.

In the nearer background of his consciousness is the life of the small town in which he experienced his early business struggles. Here he married and set up his first home. Here his children had measles and croup and he knew what it was to be on friendly terms with all sorts of neighbours. In his business, he called most of his employees by their first names and knew more or less of their personal affairs. There were few poor in the town, and they were generally shiftless or addicted to drink. Organized labour was unknown and Socialism was unheard of. A few constables represented the dignity of the Law and rounded up petty thieves and disorderly persons. The church stimulated men to overcome temptations to appetite, and to strive for a certain type of personal goodness.

Since our successful businessmen moved to the city and entered upon larger commercial and financial enterprises, the life has been very different. The greatest change lies in his isolation from the common life about him. His offices in the fine new warehouses are open only to employees of the highest rank. He throws the responsibility for details upon managers and foremen. He studies the rise and fall of markets and analyses costs. Only privileged visitors get past the outer officers to trespass upon his time. At noon he lunches at an exclusive club with men of his own group and way of thinking. He drives or is driven in his own car, so that he does not even rub shoulders with the strap-hangers in the streetcars. His home is in the best residential district, where building restrictions are rigidly enforced. After dinner with guests of his wife's set or circle, he may accompany them to the theatre. 
On Sunday, he and his family occupy a pew in St. Mark's, where everything is in the best of taste. His isolation is complete, his class consciousness assured.

He is kindhearted. He gives to the children's home, even though he protests against mothers' pensions. This is not rank hypocrisy. His early childhood and the village life gave him personal sympathy. But he has had no personal experiences of the desperate struggles of modern industrial life, and no enlightenment with regard to modern methods of social service.

He will send a Christmas basket to a poor family at Christmas but he will fight valiantly against organized labour. Again the key to his action lies in his own personal experiences with their limitations.

He thinks he knows the problems of labour because he knew his father's hired man, or knew his men in the little town where he began business twenty-five years ago. He fails to realize that just as his mahogany-finished office and beautiful residence differ widely from the old barn in which he forked back the hay or his little bedroom with the rag carpet, so an absolutely new world has grown up about him.

He has depended for his information on the newspapers and on his subordinates, and they have made only partial representations.

He has, he thinks, a mass of new data, but the new data has all been run into the old moulds - the moulds of his personal experiences in a simpler social state.

But is he not a leader in the new commercial and industrial life? Undoubtedly; but he has seen life not as a series of human relationship, but merely from the standpoint of dividends.

He thinks himself just. He would not commit a vulgar theft. He would not insult his neighbour's wife. He does not realize that he is the beneficiary of a system that is degrading womanhood and crushing out manhood. Can he be made to understand? 